\title{
Preharvest Foliar Spray of Calcium Chloride on Growth, Yield, Quality, and Shelf Life Extension of Different Lowland Tomato Varieties in Malaysia
}

\author{
Mohammad Nurun Nabi Mazumder ${ }^{1,2} \mathbb{D}$, Azizah Misran ${ }^{1, *}$, Phebe Ding ${ }^{1} \mathbb{D}$, Puteri Edaroyati Megat Wahab 1 \\ and Azhar Mohamad ${ }^{3}$ \\ 1 Department of Crop Science, Faculty of Agriculture, Universiti Putra Malaysia (UPM), \\ Serdang 43400, Selangor, Malaysia; mnnmbina@gmail.com (M.N.N.M.); phebe@upm.edu.my (P.D.); \\ putri@upm.edu.my (P.E.M.W.) \\ 2 Horticulture Division, Bangladesh Institute of Nuclear Agriculture, Bangladesh Agricultural University \\ Campus, Mymensingh 2202, Bangladesh \\ 3 Malaysian Nuclear Agency, Bangi, Kajang 43000, Selangor, Malaysia; azhar_m@nuclearmalaysia.gov.my \\ * Correspondence: azizahm@upm.edu.my; Tel.: +603-9769-4998
}

check for updates

Citation: Mazumder, M.N.N.; Misran, A.; Ding, P.; Wahab, P.E.M.; Mohamad, A. Preharvest Foliar Spray of Calcium Chloride on Growth, Yield, Quality, and Shelf Life Extension of Different Lowland Tomato Varieties in Malaysia. Horticulturae 2021, 7, 466. https:/ / doi.org/10.3390/horticulturae7110466

Received: 10 September 2021

Accepted: 26 October 2021

Published: 4 November 2021

Publisher's Note: MDPI stays neutral with regard to jurisdictional claims in published maps and institutional affiliations.

Copyright: (c) 2021 by the authors. Licensee MDPI, Basel, Switzerland. This article is an open access article distributed under the terms and conditions of the Creative Commons Attribution (CC BY) license (https:// creativecommons.org/licenses/by/ $4.0 /)$.
Abstract: Tomato is a popularly consumed vegetable fruit and suffers from huge losses due to its high perishability. Calcium chloride $\left(\mathrm{CaCl}_{2} \cdot 2 \mathrm{H}_{2} \mathrm{O}\right)$ application has been shown to be an important method that can extend the shelf life of tomato fruits. The current study aimed to determine the effect of pre-harvest treatments of $\mathrm{CaCl}_{2}$ on the growth, yield, quality, and shelf-life performance of tomato varieties. Four tomato varieties known as MT-1, MT-3, 303, and 105 were sprayed with the $\mathrm{CaCl}_{2}$ solutions $(0.0 \%, 1.0 \%, 1.5 \%$, and $2.0 \%, w / v)$ after seven days of fruit initiation and were sprayed every week until the first harvest. Spraying with $2 \%$ of $\mathrm{CaCl}_{2}$ showed an improvement in controlling physiological disorders such as blossom end rot (BER), weight loss, declined disease incidence, and disease severity. An increase in fruit quality was also observed as the treated fruit could maintain its shelf life up to 20 days at ambient conditions. At the highest doses of $\mathrm{CaCl}_{2}$ $(2 \%)$, it increased the total ascorbic acid (AA), lycopene content, total phenolic content (TPC), and antioxidant activity (DPPH) in comparison to lower doses and control tomatoes. MT-3 responded well to higher doses of $\mathrm{CaCl}_{2}(2 \%)$ among the four tomato varieties and performed better in growth, yield, disease, insect infestation, quality, and shelf-life performance compared to the other varieties and $\mathrm{CaCl}_{2}$ treatment combination.

Keywords: calcium chloride; pre-harvest; quality; shelf life; lowland tomato

\section{Introduction}

Tomato (Solanum lycopersicum L.) is a member of the nightshade family, commonly cultivated and extensively consumed among the Solanaceae family crops [1]. Tomato is an essential source of income for rural and peri-urban producers of the most developing regions of the world [2], with an annual production of 180.77 million tons in 2019 from 5.03 million hectares of land [3]. According to the literature, tomato is rich in carotenoids such as lycopene and ascorbic acid as well as antioxidants, which can reduce cardiovascular diseases and a decline in the risk of cancer in human beings [4]. Despite the numerous benefits of tomatoes, many factors such as variety, high temperature, moisture condition, high rate of respiration, and ethylene production as well as physical injuries cause postharvest losses as high as 25-42\% globally [5]. These include the high amount of quantitative and qualitative losses, resulting in minimum returns to growers, processors, traders, and the whole country suffers in terms of foreign exchange [6]. The postharvest qualities of tomatoes depend on many pre-and post-harvest factors such as the genetic, environmental factors, management practices, harvesting, and handlings methods during and after harvest [2]. 
Therefore, several pre-and postharvest interventions have been introduced to maintain quality and prolong their shelf life such as harvesting time and methods, low-temperature storage, coating, modified atmosphere packaging (MAP), and control atmosphere (CA) storage. Treatments with $\mathrm{CaCl}_{2}$ have been found to have better preservation quality on tomato fruits [7]. Calcium (Ca) is an essential macronutrient and tomato fruits contain calcium levels ranging from 3.08 to $16.42 \mathrm{mg} \mathrm{100/g}$ [8], which can be an effective treatment in reducing physiological disorder (blossom end rot), increasing the fruit firmness, delaying the ripening process, and ethylene production in tomatoes [9]. $\mathrm{CaCl}_{2}$ delays the fruit color development in tomato fruits by slowing down the ethylene production and respiration rate, thereby extending the shelf life of fruits [10]. The physiological weight loss of tomato fruits declined up to $19 \%$ by applying $0.25 \%$ of $\mathrm{CaCl}_{2}$, which maintained the higher firmness during storage [11]. The foliar application of $\mathrm{Ca}\left(0.5 \% \mathrm{CaCl}_{2}\right)$ in sweet cherry increase the Ca concentration in fruits and substantial changes in the levels of numerous primary and secondary metabolites [12-15]. Ca is essential for the formation of the cell wall and calcium pectate in the middle lamella of the cell wall, which regulates the entry of nutrients that are not toxic to plants [15]. Tomato fruits treated with $\mathrm{CaCl}_{2}$ exhibited firmer texture compared to the untreated samples due to the inhibition of polygalacturonase [10]. It is also suggested that pectate degrades and allows the calcium in the cell wall to serve as a binding agent in calcium pectate, which maintains the quality and extends the shelf life, increasing the firmness of the tomato fruits' cell walls [11].

Tomato is climacteric, highly perishable, and the losses are estimated at $25-42 \%$ worldwide due to improper postharvest techniques [2]. The choice of high-yielding tomato cultivars with desirable fruit qualities and longer shelf life is a prerequisite to a vital decision made by producers as the size, taste, color, and antioxidant activity vary depending on the genotypic variability, ripening stage, and growing conditions [16]. Very few information exists on the appropriate doses of $\mathrm{CaCl}_{2}$ for foliar application on lowland tomato varieties in Malaysia. Therefore, the objective of this investigation was to determine the effects of pre-harvest foliar spray of $\mathrm{CaCl}_{2}$ on the growth, yield, quality, and shelf life of four different tomato varieties, known as MT1, MT3, 303, and 105, which are commonly grown in lowland areas in Malaysia.

\section{Materials and Methods}

\subsection{Experimental Section}

The experiment was conducted at the greenhouse (8C) at the Agro-Tech Unit, Ladang 15, Faculty of Agriculture, Universiti Putra Malaysia (UPM), Serdang, Selangor from September 2019 to February 2020. The present study was carried out at the lowland areas of Malaysia, which represent high ambient temperature, high humidity, and the average day temperature was $33.24{ }^{\circ} \mathrm{C}\left(36.45^{\circ} \mathrm{C}\right.$ inside the glasshouse) with an average day relative humidity of $78.84 \%$ (73.57\% inside the glasshouse).

\subsubsection{Plant and Planting Materials}

The tomato seeds were germinated in the germination trays and seeds of four tomato varieties (Figure A1): MT1, MT3 high yielding tomato varieties (from the Malaysia Research and Development Institute (MARDI), 303 (Hybrid Super Star, Green World), and 105 ( $\mathrm{F}_{1}$ Hybrid, Green Eagle) [17]. The medium for germination was peat moss and bio-soil (3:1) and a total of 10 germination trays were used to germinate the tomato seedlings. The media for the planting of tomato plants was coco peat $(2.5 \mathrm{~kg} / \mathrm{bag})(\mathrm{pH}: 6.6, \mathrm{EC}: 0.16$, Ca: $2.17 \mathrm{mg} / \mathrm{g}, \mathrm{K}: 15.25 \mathrm{mg} / \mathrm{g} \mathrm{Mg}: 1.2 \mathrm{mg} / \mathrm{g}$ ) and the dried media were placed in black poly bags (size $18^{\prime \prime} \times 18^{\prime \prime}$ ) containing a sufficient number of holes ( 32 holes) for drainage purposes. After three weeks, the vigorous and healthiest seedlings were extracted from the germination trays, placed in the polybag, and then the freshwater was supplied by pre-setting a fertigation system. The planting media coco peat contained approximately $2.17 \mathrm{mg} / \mathrm{g} \mathrm{Ca}$ [18] and the irrigation water had 30-60 ppm of Ca [19]. Nutrient solutions A and $\mathrm{B}$ were used as fertilizer and the doses ranges calculated by the EC measurement (rang- 
ing EC 0.5-2.5 transplanting to harvest). Tomato seedlings were transplanted following the standard spacing of $60 \mathrm{~cm}$ between plant to plant and $75 \mathrm{~cm}$ between row to row.

\subsubsection{Pre-Harvest Application of $\mathrm{CaCl}_{2}$}

The pre-harvest spray of different concentrations of $\mathrm{CaCl}_{2} \cdot 2 \mathrm{H}_{2} \mathrm{O}$ was $\mathrm{T}_{0}=0.0 \%$ (apply $1000 \mathrm{~mL}$ water), $\mathrm{T}_{1}=1.0 \%$ (10 g CaCl in $1000 \mathrm{~mL}$ water), $\mathrm{T}_{2}=1.5 \%\left(15 \mathrm{~g} \mathrm{CaCl}_{2}\right.$ in $1000 \mathrm{~mL}$ water), and $\mathrm{T}_{3}=2.0 \%$ ( $20 \mathrm{~g} \mathrm{CaCl}_{2}$ in $1000 \mathrm{~mL}$ water) were applied in the morning. The spray was mixed with Tween $20(0.03 \%, v / v)$ and applied as a foliar application after one week of fruit initiation (when the average fruit in the second cluster was approximately $1.5 \mathrm{~cm}$ in diameter) every week of the interval until it was ready to harvest.

\subsection{Measurement of Growth and Yield Parameters}

The growth is considered by collecting plant height $(\mathrm{cm})$, which was measured from the base to the apical part of the plants at the end of the experiment using a wooden meter ruler. The number of branches, flower and fruit initiation time, and the total number of fruits were determined by counting at every weekly interval and the total fruit weight $(\mathrm{kg})$ per plant and total yield ( $t / h a)$ were recorded up to the last commercial harvest [20]. The disease and insect infestations were determined by counting infected leaf, stem, and whole plants as the percentage of total plants. The physiological disorder, especially blossom end rot (BER), was determined by counting affected mature and immature fruits as the percentage of the total number of fruits. The parameter yield is the total number and weight $(\mathrm{kg})$ of fresh fruit $(\mathrm{kg})$ per plant, which was converted to ton per hectare considering the standard number of 20,000 plants per hectares.

\subsection{Determination of Quality Parameters}

\subsubsection{Selection of Fruits}

Tomato fruits are harvested manually at the red ripe stage (stage 6) in December 2019 to investigate the shelf life, quality, and postharvest performance. Fruits of uniform size, color, undamaged, and free from disease and bruises were selected for experimental purposes [6]. Fresh fruit were used to measure some quality parameters instantly such as firmness, SSC, and TA, whereas the refrigerated samples were used to analyze the physicochemical characteristics.

\subsubsection{Firmness}

The firmness of the tomato fruits was determined by a Universal Testing Machine (Model 5543, load frame, Instron Corp., University Avenue Norwood, Norwood, MA, USA) with a $6 \mathrm{~mm}$ diameter cylindrical probe at a speed of $20 \mathrm{~mm} / \mathrm{min}$ along with an Instron Merlin software, version M12-13664-EN, and a reading for each sample was recorded in Newton (N) [21].

\subsubsection{Soluble Solid Concentration (SSC)}

The soluble solid concentration of tomato fruits was determined by a digital pocket refractometer (model PAL1, ATAGO ${ }^{\mathrm{TM}}$ Tokyo Tech, Minato city, Japan). The SSC (\% Brix) was obtained by dropping fresh fruit juice on the glass lens of the refractometer collected from the fresh tomato fruits using a garlic pester (kitchen apparatus) and the value was expressed as the Brix percentage (\% Brix) [22].

\subsubsection{Titratable Acidity (TA)}

The titratable acidity was determined by using titration methods. About $10 \mathrm{~g}$ of pulp tissue from tomato fruits mixed with $20 \mathrm{~mL}$ distilled water was blended by a kitchen blender (MX-799S, Panasonic), homogenized, and filtered using cotton wool. Two drops of phenolphthalein indicator ( $1 \%$ dye) was added to a $5 \mathrm{~mL}$ titrate followed by titration with $0.1 \mathrm{~N}$ sodium hydroxide $(\mathrm{NaOH})$ up to the endpoint due to the appearance of a pink color $(\mathrm{pH} 8.1)$. The volume of titrate added was recorded and the results were expressed 
as the percentage of citric acid per $100 \mathrm{~g}$ fresh weight following the methods described by Mohammadi-Aylar et al. [23].

Titratable acidity $(\%)=\frac{\text { Titer vol. }(\mathrm{ml}) \times \text { normality } \mathrm{NaOH}(0.1) \times \text { vol. made up }(20 \mathrm{ml}) \times 64 \mathrm{~g}(\text { equivalent wt. of citric acid }) \times 100}{\text { Wt. of sample }(5 \mathrm{~g}) \times \text { vol. of sample for titration }(5 \mathrm{ml}) \times 1000}$

\subsubsection{Antioxidant Properties}

Ascorbic Acid

Direct colorimetric methods were used to determine the ascorbic acid using 2,6Dichlorophenol-indophenol (DCPIP) dye [24]. About $2 \mathrm{~g}$ of tomato samples were mixed with $20 \mathrm{~mL}$ of metaphosphoric acid, $\mathrm{HPO}_{3}(2 \%)$, and extracted, filtered with cotton wool, and diluted to make a volume of $40 \mathrm{~mL}$ with more $\mathrm{HPO}_{3}(2 \%)$. The aliquot $(0.5 \mathrm{~mL})$ was mixed with $3 \mathrm{~mL}$ of $\mathrm{HPO}_{3}(2 \%)$ followed by a $2 \mathrm{~mL}$ dye solution, and the absorbance at the $518 \mathrm{~nm}$ wavelength was measured immediately using a UV spectrophotometer (Spectrophotometer-1510, Thermo Fisher Scientific, Vantaa, Finland). The standard curve was used to determine the concentration of ascorbic acid in tomato fruit and expressed as $\mathrm{mg} / \mathrm{g}$ fresh weight.

AA $(\mathrm{mg} / \mathrm{g} \mathrm{FW})=[($ Conc. of sample soln. as ppm computed from the standard curve) $\times$ Final vol. made up in liter $(0.04 \mathrm{~L})] /$ Fresh wt. of the samples $(\mathrm{g})$

Lycopene

The lycopene determination was carried out by following the slightly modified methods of Nagata and Yamashita [25]. About $1 \mathrm{~g}$ of sample was mixed with the solvent of $10-20 \mathrm{~mL}$ of acetone and hexane (acetone:hexane $=4: 6$ ). The pigments were extracted with a mortar and pestle, homogenized, and the supernatant was automatically separated. The optical density was taken immediately at $663 \mathrm{~nm}, 645 \mathrm{~nm}, 505 \mathrm{~nm}$, and $453 \mathrm{~nm}$ using a UV spectrophotometer and the amount of lycopene were determined by the following equation described below:

$$
\text { Lycopene }(\mathrm{mg} / 100 \mathrm{~g})=-0.0458 \mathrm{~A}_{663}+0.204 \mathrm{~A}_{645}+0.372 \mathrm{~A}_{505}-0.0806 \mathrm{~A}_{453}
$$

$\mathrm{A}_{663}, \mathrm{~A}_{645}, \mathrm{~A}_{505}$, and $\mathrm{A}_{453}$ are the absorbance at $663 \mathrm{~nm}, 645 \mathrm{~nm}, 505 \mathrm{~nm}$, and $453 \mathrm{~nm}$ of each other. Data obtained as $\mathrm{mg} / 100 \mathrm{~mL}$ were further converted as data $\mathrm{mg} / 100 \mathrm{~mL} \times$ sample volume $=$ data $\mathrm{mg} / 100 \mathrm{~g}$.

\section{Extraction for Antioxidant Determination}

Tomato sample of $3 \mathrm{~g}$ weight was ground using a pestle and mortar. The ground sample was poured into a dark-colored tube containing $8 \mathrm{~mL}$ of $80 \%(v / v)$ methanol and then mounted on an orbital shaker and shaken for one hour at $180 \mathrm{rpm}$. Afterward, the mixture was filtered using No. 1 Whatman filter paper, then the supernatant was ready for the determination of DPPH and TPC. The supernatant was stored in the chiller until used for experiment. The method was carried out according to Addai et al. [26] with slight modification.

\section{Total Phenolic Content (TPC)}

The determination of TPC was conducted by following the methods described by Musa et al. [27] with slight modification. The supernatant of $150 \mu \mathrm{L}$ was taken and mixed with $750 \mu \mathrm{L}$ of $10 \%$ Folin-Ciocalteu reagent (FCR) and then incubated for five minutes. This was followed by the addition of $600 \mu \mathrm{L}$ of $7.5 \%(w / v)$ sodium carbonate $\left(\mathrm{Na}_{2} \mathrm{CO}_{3}\right)$. Furthermore, the mixture was once again incubated for another $30 \mathrm{~min}$ in the dark. The absorbance was subsequently taken at $765 \mathrm{~nm}$ using a UV spectrophotometer. After $30 \mathrm{~min}$ of incubation, the absorbance was taken at a $765 \mathrm{~nm}$ wavelength using a UV spectrophotometer. The results were expressed as $\mathrm{mg}$ of gallic acid equivalents per $100 \mathrm{~g}$ of fresh sample (mg GA/100 $g$ of FW). 


\section{DPPH Radical Scavenging Assay}

The antioxidant activity was determined by the DPPH (2,2- diphenyl-1-picrylhydrazyl) free radical scavenging methods described by Musa et al. [27]. The stock solution of $1 \mathrm{mM}$ DPPH was prepared by dissolving $40 \mathrm{mg}$ of DPPH in $100 \mathrm{~mL}$ of $80 \%$ methanol and kept in a chiller until used. The supernatant of about $1 \mathrm{~mL}$ was mixed with $1 \mathrm{~mL}$ of $1 \mathrm{mM}$ DPPH and incubated for $30 \mathrm{~min}$ in the dark. The absorbance was taken immediately after incubation at the $517 \mathrm{~nm}$ wavelength of the UV spectrophotometer and the percentage of antioxidant activity was determined using the following equation:

$$
\text { DPPH scavenging activity }(\%)=\left(\mathrm{A}_{\text {blank }}-\mathrm{A}_{\text {sample }} / \mathrm{A}_{\text {blank }}\right) \times 100
$$

where $\mathrm{A}$ is for absorbance.

\subsubsection{Respiration and Ethylene Production}

The harvested tomato fruits were placed into a $1.9 \mathrm{~L}$ plastic container purged and airtight. After $2 \mathrm{~h}$, at ambient temperature $\left(25-30{ }^{\circ} \mathrm{C}\right)$, the respiration rate was determined by measuring the $\mathrm{CO}_{2}$ concentration produced in the outflow from each chamber. About $1 \mathrm{~mL}$ of the headspace gas sample was withdrawn by a gastight syringe from the incubation chamber, then injected into the GC (gas chromatography, Clarus 500, PerkinElmer instrument, Waltham, MA, USA) to determine the $\mathrm{CO}_{2}$ for respiration and ethylene production [28].

\subsection{Postharvest Storage Evaluation}

Five fruits from each replication were selected for postharvest experiments stored in a polybag (size $26 \mathrm{~cm} \times 18 \mathrm{~cm}$, thickness $0.05 \mathrm{~mm}$ ), the number of holes were 18 , and the diameter of the holes was $0.5 \mathrm{~cm}$, which was also stored in a paper carton (size $30 \mathrm{~cm} \times 25 \mathrm{~cm} \times 10.6 \mathrm{~cm}$ ) where the thickness was $2.0 \mathrm{~mm}$, contained 16 holes and the hole size was $2 \mathrm{~cm} \times 0.8 \mathrm{~cm}$ at ambient condition $\left(28 \pm 2{ }^{\circ} \mathrm{C}, 70 \pm 5 \% \mathrm{RH}\right)$. The temperature and humidity were measured by a digital in/out thermo-hygrometer. The percent weight loss, disease incidence, disease severity percent (scale), and percent visual symptoms (lesions caused by grey mold, soft rot, and insect infestation) of fruits were recorded at intervals of 0 days, five days, 10 days, 15 days, and 20 days. In the case of shelf life performance, it was observed up to the final stage of the deterioration of maximum tomato fruits.

\subsubsection{Weight Loss}

The stored fruits were observed regularly and weighed every five days and the difference in weight loss was expressed as accumulated percentage weight loss by the following equation in Nirupama et al. [22].

$$
\text { Weight loss }(\%)=\frac{\text { Initial weight }- \text { Weight at sampling date }}{\text { Initial weight }} \times 100
$$

\subsubsection{Disease Incidence and Disease Severity}

Data on disease incidence were estimated by visual observation and the data on disease severity were indexed on a 0 to 4 scale $(0=0 \%, 1=1-25 \%, 2=26-50 \%, 3=51-75 \%$, and $4 \geq 76 \%$ of fruit surface rotten symptoms). Disease incidence percent and disease severity percent were recorded according to the following formula described by Amadi et al. [29]. Disease incidence and disease severity were observed every five days in storage up to the maximum storage duration (20 days) for each treatment (each block of ten fruits).

$$
\text { Disease Incidence }(\mathrm{DI})(\%)=\frac{\text { No. of rotten fruits }}{\text { No. of total fruits }} \times 100
$$


Disease Severity $($ DS $)(\%)=\frac{\sum(\text { Severity rating } \times \text { number of fruits in this rating })}{(\text { Total number of fruit assess } \times \text { highest scale })} \times 100$

\subsubsection{Fruit Decay and Shelf Life}

Observations of visual symptoms were carried out at intervals of every five days taking into consideration the skin shrinkage (due to dehydration), disease incidence percent, and disease severity (scale) of fungal mycelial growth. Similarly, the percent decay was expressed as the percent visual symptoms (VS) or percent non-marketable fruits (NMF). The shelf life was determined by storing the fruits up to the appearance of the final deterioration of maximum fruits stored at ambient temperature (temp. $28 \pm 2{ }^{\circ} \mathrm{C}$ and $75 \pm 5 \% \mathrm{RH}$ ). The decay percent can be expressed as the accumulated percentage of the total decay fruits divided by the initial fruit numbers Amadi et al. [29].

$$
\mathrm{VS} / \mathrm{NMF}(\%)=\frac{\sum(\mathrm{VS} / \mathrm{NMF} \text { rating } \times \text { number of fruits in this rating })}{(\text { Total number of fruit assess } \times \text { highest scale })} \times 100
$$

where VS is the visual symptom and NMF is non-marketable fruits.

\subsection{Experimental Design and Statistical Analysis}

The experiment was conducted using CRD design with two factors in the glasshouse condition and quality analysis as plant performance and CRD design with three factors in the postharvest performance experiment in the laboratory. There were four varieties, namely MT-1, MT-3, 303, and 105, and four concentrations of $\mathrm{CaCl}_{2},\left[\mathrm{~T}_{0}=0.0 \%\right.$ (spray freshwater), $\mathrm{T}_{1}=1.0 \%, \mathrm{~T}_{2}=1.5 \%$, and $\mathrm{T}_{3}=2.0 \% \mathrm{w} / \mathrm{v}$ ], which was further replicated four times. The data analysis was subjected to ANOVA using the SAS software (version 9.4) [30]. The treatment means were compared by least significant difference (LSD) at the $5 \%$ probability level. The regression and combined analysis were performed to determine the relationships between the variables of varieties, concentrations of $\mathrm{CaCl}_{2}$, and the different intervals (days) for the postharvest shelf life experiment.

\section{Results and Discussion}

\subsection{Growth and Yield Contributing Characteristics}

There were no significant two-way interaction effects $(p>0.05)$ among the tomato varieties (MT-1, MT-3, 303, and 105) and $\mathrm{CaCl}_{2}$ concentrations $(0,1,1.5,2, w / v \%)$ on the number of branches, flower initiation at different days after transplanting (DAT), total number of fruits, fruit weight, and total yield (Table 1). Although there were no interaction effects between the two factors, significant differences were observed in different varieties of tomato on the number of branches, flower at DAT, number of fruits, fruit weight, and total fruit yield. The number of branches of variety MT-1 and MT-3 were significantly higher compared to other varieties. In contrast, variety 303 showed the lowest number of branches, approximately $27-30 \%$ lower than in MT- 1 and MT-3, respectively. In the case of plant height, variety 303 produced the tallest plant and it was $17 \%, 12 \%$, and $8 \%$ higher than the varieties of MT-1, MT-3, and 105, respectively.

Although variety 105 showed earlier flower initiation, it produced the highest number of fruits statistically similar to MT-3 (39 fruits/plant). The total number of fruits of 105 and MT-3 were $10.25 \%$ and $30.77 \%$ higher than the varieties MT- 1 and 303, respectively. Besides that, the tomato fruits of variety 105 yielded the highest total yield, which was $8-27 \%$ higher than the other varieties and variety 303 produced the lowest number of fruits. Still, the size was more significant compared to the others.

No significant $(p>0.05)$ differences were found regarding the application of $\mathrm{CaCl}_{2}$ on planting tomatoes except for the total number of fruits and total yield. In terms of yield, the planting of tomatoes with $2 \% \mathrm{CaCl}_{2}$ application yielded the lowest production compared to the other treatments and control samples, respectively (Table 1). 
Table 1. The mean and interaction effects of all tomato varieties (MT-1, MT-3, 303, and 105) and different concentrations of $\mathrm{CaCl}_{2}(0,1,1.5,2, w / v \%)$ on the plant height, no. of branches, the total number of fruits, fruit weight $(\mathrm{g})$, and total yield $(\mathrm{t} / \mathrm{ha})$.

\begin{tabular}{|c|c|c|c|c|c|}
\hline Treatment & $\begin{array}{c}\text { No. of } \\
\text { Branches }\end{array}$ & $\begin{array}{l}\text { Plant Height } \\
(\mathrm{cm})\end{array}$ & $\begin{array}{c}\text { Total Number } \\
\text { of Fruits }\end{array}$ & $\begin{array}{l}\text { Individual Fruit } \\
\text { Weight (g) }\end{array}$ & $\begin{array}{c}\text { Total Yield } \\
(\mathrm{t} / \mathrm{ha})\end{array}$ \\
\hline \multicolumn{6}{|l|}{ Variety } \\
\hline MT-1 & $47.25 \mathrm{a}$ & $131.60 \mathrm{c}$ & $35 \mathrm{~b}$ & $23.85 \mathrm{c}$ & $18.38 \mathrm{~b}$ \\
\hline MT-3 & $48.38 \mathrm{a}$ & $137.22 \mathrm{c}$ & $39 a$ & $26.57 \mathrm{~b}$ & $21.14 \mathrm{a}$ \\
\hline 303 & $37.31 \mathrm{c}$ & $153.40 \mathrm{a}$ & $27 \mathrm{c}$ & $30.91 \mathrm{a}$ & $17.98 \mathrm{~b}$ \\
\hline 105 & $43.00 \mathrm{~b}$ & $141.77 \mathrm{~b}$ & $39 a$ & $26.20 \mathrm{bc}$ & $22.80 \mathrm{a}$ \\
\hline \multicolumn{6}{|l|}{$\mathrm{CaCl}_{2}(w / v, \%)$} \\
\hline 0 & $42.44 \mathrm{a}$ & $141.79 \mathrm{a}$ & $39 a$ & $27.12 \mathrm{a}$ & $21.73 \mathrm{a}$ \\
\hline 1 & $45.81 \mathrm{a}$ & $140.36 \mathrm{a}$ & $34 \mathrm{~b}$ & $27.20 \mathrm{a}$ & $20.93 \mathrm{ab}$ \\
\hline 1.5 & $44.50 \mathrm{a}$ & $141.97 \mathrm{a}$ & $34 \mathrm{~b}$ & $28.30 \mathrm{a}$ & $19.22 b c$ \\
\hline 2 & $43.20 \mathrm{a}$ & 139.87 a & $34 b$ & $25.51 \mathrm{a}$ & 18.42 c \\
\hline $\begin{array}{c}\text { Interaction } \\
\left(\text { Variety } \times \mathrm{CaCl}_{2}\right)\end{array}$ & ns & ns & ns & ns & ns \\
\hline LSD & 4.53 & 4.99 & 2.95 & 2.58 & 2.14 \\
\hline
\end{tabular}
using the LSD test. ns = not significant.

The application of $\mathrm{CaCl}_{2}$ did not show any effects on the number of fruits and total yield, which disagreed with Ayyub et al. [31], where the highest numbers of fruit per plant and fruit weight per plant with the application of $0.5 \mathrm{M} \mathrm{CaCl}_{2}$. In our findings, the lower production may be due to the genetic characteristics of the varieties and the application of foliar spray after fruit initiation and did not contribute to the growth and yield of tomato fruits. However, it was reported that $\mathrm{CaCl}_{2}$ increases the fruit weight and yield of many crops such as the tomato cv. 'Rajitha' exhibited a significant reduction in fresh weight [32], which resembled the findings of our present experiment.

Disease and Insect Infestation

The presented data in Table 2 did not show any significant effects $(p>0.05)$ among the tomato varieties and the concentrations of $\mathrm{CaCl}_{2}$ on insect infestation, especially whiteflies and blossom end rot symptoms. Although all tomato plants were infested by whiteflies (WF), 303 and 105 showed the highest susceptibility and the infestation was $66 \%$ and $71 \%$ higher than the inbred varieties of MT-1 and MT-3, respectively. As the infestation of whiteflies started at an early stage of plant growth and development, the effect of $\mathrm{CaCl}_{2}$ on the infestation of whiteflies was very low and did not show any significant difference.

Table 2. The mean and interaction effects of all tomato varieties (MT-1, MT-3, 303, and 105) and different concentrations of $\mathrm{CaCl}_{2}(0,1,1.5,2, w / v \%)$ on white fly infestation, early blight infection, and blossom end rot symptoms of different tomato varieties.

\begin{tabular}{ccc}
\hline Treatment & Whitefly-Infected Leaf (\%) & Early Blight-Infected Leaf (\%) \\
\hline Variety & $2.20 \mathrm{~b}$ & $10.75 \mathrm{~b}$ \\
MT-1 & $2.12 \mathrm{~b}$ & $3.29 \mathrm{ab}$ \\
MT-3 & $6.25 \mathrm{a}$ & $24.50 \mathrm{a}$ \\
303 & $7.37 \mathrm{a}$ & $26.00 \mathrm{a}$ \\
105 & & \\
$\mathrm{CaCl}_{2}(w / v, \%)$ & $3.94 \mathrm{a}$ & $4.62 \mathrm{a}$ \\
0 & $4.06 \mathrm{a}$ & $4.06 \mathrm{a}$ \\
1 & $4.93 \mathrm{a}$ & $4.62 \mathrm{a}$ \\
1.5 & $4.31 \mathrm{a}$ & $3.75 \mathrm{a}$ \\
2 & $\mathrm{~ns}$ & $\mathrm{~ns}$ \\
Interaction & & 0.02 \\
LSD & 0.02 & $\left.\mathrm{CaCl}_{2}\right)$
\end{tabular}

Means within a factor and column followed by the same alphabet were not significantly different at $p=0.05$ by using the LSD test. ns = not significant. 
Common tomato diseases such as early blight (fungus Alternaria solani) infection occurred primarily on the leaf and stem of all varieties after fruit initiation and the rate of infections were significantly different $(p<0.05)$ among the varieties. Still, no significant $(p>0.05)$ difference was observed in the case of $\mathrm{CaCl} 2$ treatments (Table 2$)$. The early blight infection was estimated at approximately $20-25 \%$ plants of all varieties after fruit initiation and the two-hybrid varieties (303 and 105) showed the highest infected leaf, 50\% to 71\% compared to the varieties of both MT-1 and MT-3, respectively.

The symptoms of the physiological disorder (blossom end rot) were estimated by counting the total number of infected fruits in percent. The observation of blossom end rot on the varieties MT- 1 and MT-3 did not show any symptoms whereas the hybrid varieties 105 and 303 showed few symptoms in the control and lower doses $(1 \%, 1.5 \%)$ of $\mathrm{CaCl} 2$-treated tomato fruits (Figures 1 and $\mathrm{A} 2$ ).
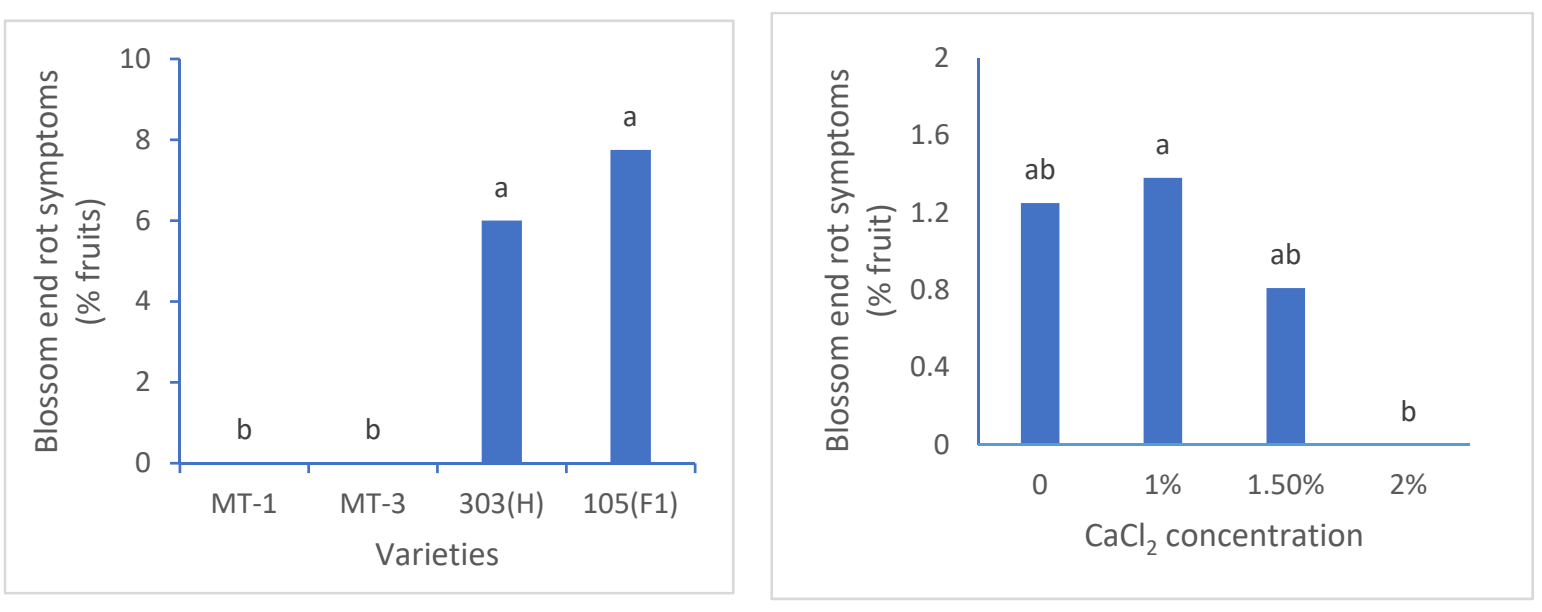

Figure 1. Effects of varieties of MT-1, MT-3, 303(H), and $105(\mathrm{~F} 1)$ and $\mathrm{CaCl}_{2}$ concentrations of $0,1,1.5$, and $2 \%(w / v)$ on blossom end rot symptoms (\% fruits). Means with the same letter were not significantly different by the LSD test at $p>0.05$.

These results led to a similar conclusion from the findings of Abbasi et al. [9], who described that the occurrence of BER significantly declined at the highest doses of $\mathrm{CaCl}_{2}$ $(1.65 \%)$ compared to the control treatments. Rab and Haq [33] described that the preharvest application of $\mathrm{CaCl}_{2}$ significantly declined the blossom end rot incidence in tomato fruits. The symptoms of the blossom end rot of tomatoes are physiological disorder, which generally resulted from calcium deficiency in fruits or the aggravated effects due to the depletion of many other nutrients along with Ca such as $\mathrm{NH}_{4}-\mathrm{N}, \mathrm{K}$, and $\mathrm{Mg}$ [33].

\subsection{Postharvest Performance}

\subsubsection{Respiration and Ethylene Production}

The presented data of ethylene production and respiration rate were not significantly different $(p>0.05)$ among the varieties and the concentrations of $\mathrm{CaCl}_{2}$ (Table 3$)$.

The varieties MT-1 and 105 demonstrated a $56.56 \%$ to $83.76 \%$ lower ethylene production rate than the varieties MT-3 and 303, respectively, in storage conditions. The $\mathrm{CaCl}_{2}$ doses of $1.5 \%$ decreased ethylene production $16.14 \%$ compared to the control samples whereas the highest amounts of $\mathrm{CaCl}_{2}(2 \%)$ increased ethylene production by $19.27 \%$ compared to the control samples, indicating that $1.5 \% \mathrm{CaCl}_{2}$ was effective for reducing postharvest ethylene production in tomato fruits at ambient storage conditions. The findings of our experiments were supported by the study by Senevirathna and Daundasekera [10], which observed that $\mathrm{CaCl}_{2}$-treated tomatoes produced lower ethylene compared to the untreated ones.

The interaction effects of different low land tomato varieties and the concentrations of $\mathrm{CaCl}_{2}$ exhibited non-significance $(p>0.05)$ on the respiration rate, but significant effects $(p<0.05)$ occurred among the varieties and $\mathrm{CaCl}_{2}$ concentrations (Table 3$)$. The tomato 
varieties MT-1 and 105 had lower respiration rates of about $10.40 \%$ to $34.24 \%$ than the varieties MT-3 and 303. The higher doses of $\mathrm{CaCl}_{2}(2 \%)$ had a decreased rate of respiration ranging from $22.05 \%$ to $44.11 \%$ compared to the lower doses $(1 \%, 1.5 \%)$ and control samples, respectively.

Table 3. The mean and interaction effects of all tomato varieties (MT-1, MT-3, 303, and 105) and different concentrations of $\mathrm{CaCl}_{2}(0,1,1.5,2, w / v \%)$ on ethylene production, rate of respiration, firmness, soluble solid contents, and titratable acidity after harvest at room temperature $\left(28 \pm 2{ }^{\circ} \mathrm{C}\right.$, $75 \pm 5 \% \mathrm{RH})$.

\begin{tabular}{|c|c|c|c|c|c|}
\hline Treatment & $\begin{array}{l}\text { Ethylene Production } \\
\quad\left(\mu \mathrm{L} \mathrm{C} \mathrm{C}_{2} \mathrm{H}_{4} / \mathrm{kg} / \mathrm{h}\right)\end{array}$ & $\begin{array}{l}\text { Respiration Rate } \\
(\mathrm{mL} \mathrm{CO} / \mathrm{kg} / \mathrm{h})\end{array}$ & $\begin{array}{l}\text { Firmness } \\
(\mathrm{N})\end{array}$ & $\begin{array}{c}\text { SSC } \\
\text { (\% Brix) }\end{array}$ & $\begin{array}{r}\text { Titratable } \\
\text { Acidity (\%) }\end{array}$ \\
\hline \multicolumn{6}{|l|}{ Variety } \\
\hline MT-1 & $149.83 \mathrm{a}$ & $2.95 \mathrm{~b}$ & $9.64 \mathrm{~b}$ & $4.48 \mathrm{a}$ & $0.68 \mathrm{a}$ \\
\hline MT-3 & $158.59 \mathrm{a}$ & $3.29 \mathrm{ab}$ & $12.98 \mathrm{a}$ & $4.76 \mathrm{a}$ & $0.75 \mathrm{a}$ \\
\hline 303 & $234.58 \mathrm{a}$ & 3.96 a & $9.12 \mathrm{~b}$ & $3.76 \mathrm{~b}$ & $0.53 \mathrm{~b}$ \\
\hline 105 & $127.65 \mathrm{a}$ & $2.98 \mathrm{~b}$ & $9.37 \mathrm{~b}$ & $3.91 \mathrm{~b}$ & $0.51 \mathrm{~b}$ \\
\hline \multicolumn{6}{|l|}{$\mathrm{CaCl}_{2}(\%)$} \\
\hline 0 & $191.65 \mathrm{a}$ & $3.79 \mathrm{a}$ & $9.71 \mathrm{~b}$ & $4.37 \mathrm{a}$ & $0.64 \mathrm{a}$ \\
\hline 1 & $185.51 \mathrm{a}$ & $3.55 \mathrm{a}$ & $9.23 \mathrm{~b}$ & $4.10 \mathrm{a}$ & $0.64 \mathrm{a}$ \\
\hline 1.5 & $165.02 \mathrm{a}$ & $3.21 \mathrm{ab}$ & $10.22 \mathrm{~b}$ & $4.19 \mathrm{a}$ & $0.61 \mathrm{a}$ \\
\hline 2 & $228.58 \mathrm{a}$ & $2.63 \mathrm{~b}$ & $11.95 \mathrm{a}$ & $4.24 \mathrm{a}$ & $0.58 \mathrm{a}$ \\
\hline $\begin{array}{c}\text { Interaction } \\
\left(\text { Variety } \times \mathrm{CaCl}_{2}\right)\end{array}$ & ns & ns & ns & ns & ns \\
\hline LSD & 142.36 & 0.75 & 1.51 & 0.52 & 0.11 \\
\hline
\end{tabular}
using the LSD test. ns = not significant.

The decline in respiration rate by applying higher doses of $\mathrm{CaCl}_{2}$ may increase the fruit firmness and rigidity. The cell wall, where pectin polymers are mainly considered responsible for fruit firmness, can present glycosidic chains interconnected by phenolic compounds [34]. These phenolic compounds retarded the respiration rate and ethylene production by slowing down the metabolic activity and prolonging the shelf life of tomato fruits [10].

\subsubsection{Firmness}

The data presented in Table 3 show that the interaction between the tomato varieties and concentrations of $\mathrm{CaCl}_{2}$ on firmness were not significant $(p>0.05)$, but there was a significant $(p<0.05)$ effect within the varieties and $\mathrm{CaCl}_{2}$ treatments. The fruits of the variety MT-3 showed the highest firmness of $25.35 \%$ to $29.74 \%$ compared with the other varieties. The foliar spray of $\mathrm{CaCl}_{2}$ showed highly positive effects on the firmness of tomato fruits and the firmness was $14.48 \%$ to $22.76 \%$ higher at $2 \% \mathrm{CaCl}_{2}$ compared to the lower doses and untreated samples, respectively.

The present findings were similar to the recommendations presented by Daundasekera et al. [31] where tomatoes treated with $\mathrm{CaCl}_{2}$ exhibited significantly $(p<0.05)$ higher firmness than the non-treated samples. The $\mathrm{CaCl}_{2}$ interacts with the pectic acid of fruits, forming a calcium pectate complex that results in a maintained cell wall structure that increased the rigidity of middle lamella of tomato fruits [10]. On the other hand, the $\mathrm{CaCl}_{2}$ also regulates the enzymatic activities (resistance against degrading enzymes e.g., polygalacturonase) responsible for the softening of fruits [7]. The firmness of fruits increased by $\mathrm{CaCl}_{2}$ has already been reported by Madani et al. [35] in papaya, suggested that $\mathrm{CaCl}_{2}$ reduced fruit softening and maintaining the firmness in storage conditions.

\subsubsection{Soluble Solid Content (SSC) and Titratable Acidity (TA)}

In the ripening process of tomatoes, due to the breakdown of polysaccharides, the content of SSC usually occurred as positive changes (i.e., increases). The interaction among the different tomato varieties and $\mathrm{CaCl}_{2}$ concentration was not significant $(p<0.05)$ on the quality attributes of soluble solid content and titratable acidity, but were significantly different within the varieties (Table 3). The tomato fruits of MT-3 showed the highest 
soluble solid concentration of $6.25 \%$ to $16.07 \%$ compared to the others and the variety MT-3 had the higher titratable acidity of $9.33 \%$ to $32 \%$, respectively, with other varieties. The pre-harvest application of $\mathrm{CaCl}_{2}$ did not show a significant $(p<0.05)$ effect on SSC and TA, but the application of higher doses $(1.5 \%$ and $2 \%$ ) declined the percentage of Brix than the lower doses and the untreated samples. In the fruits and vegetables of higher plants, calcium binds with the pectin contents, forming a salt bridge between $\mathrm{Ca}^{2+}$ and $\mathrm{COO}^{-}$ group that provide sites for the binding of $\mathrm{Ca}$ [9]. The newly formed calcium pectate reduces the cell wall's degradation, resulting in maintaining a low SSC by slowing down the ripening process. The studies by Bhattarai and Gautam [11] and Peyvast et al. [36] on tomato fruits presented a similar conclusion to the present experiment.

Titratable acidity is related to the concentration of organic acids (mainly citric acid) present in the fruits as free acid, anions, or combined as a salt, which declined during ripening as they are respired and converted to sugar [4]. The present investigation showed that TA did not show any significant $(p>0.05)$ differences among the doses of $\mathrm{CaCl}_{2}$. However, higher doses caused a slight decrease in the TA (Table 3) and a similar pattern of results was obtained by Mujtaba et al. [37] where $2 \% \mathrm{CaCl}_{2}$ effectively decreased the acidity of tomato fruits indicating the decreasing rate of respiration.

\subsubsection{Antioxidant Properties}

Ascorbic Acid and Lycopene

No significant differences $(p>0.05)$ were observed in the amount of ascorbic acid content while lycopene showed significant $(p<0.05)$ effects between the interaction of varieties and concentration of $\mathrm{CaCl}_{2}$ (Table 4$)$.

Table 4. The mean and main interaction effects of tomato varieties (MT-1, MT-3, 303, and 105) and different concentrations of $\mathrm{CaCl}_{2}(0,1,1.5,2 w / v \%)$ on ascorbic acid content, lycopene content, total phenolic content (TPC), and DPPH scavenging activity after harvest stored at ambient temperature $\left(28 \pm 2{ }^{\circ} \mathrm{C}, 75 \pm 5 \% \mathrm{RH}\right)$.

\begin{tabular}{|c|c|c|c|c|}
\hline Treatment & $\begin{array}{c}\text { Ascorbic Acid } \\
\text { (mg/g FW) }\end{array}$ & $\begin{array}{c}\text { Lycopene } \\
\text { (mg/100 g FW) }\end{array}$ & $\begin{array}{c}\text { TPC } \\
(\mathrm{mg} / \mathrm{g} \text { FW) }\end{array}$ & $\begin{array}{c}\text { DPPH Scavenging } \\
\text { Activity (\%) }\end{array}$ \\
\hline \multicolumn{5}{|l|}{ Variety } \\
\hline MT-1 & $0.54 \mathrm{a}$ & $2.02 \mathrm{~b}$ & $0.30 \mathrm{ab}$ & $55.42 \mathrm{a}$ \\
\hline MT-3 & $0.43 \mathrm{a}$ & $2.47 \mathrm{a}$ & $0.39 \mathrm{a}$ & $55.25 \mathrm{a}$ \\
\hline 303 & $0.58 \mathrm{a}$ & $2.06 \mathrm{ab}$ & $0.38 \mathrm{a}$ & $65.99 \mathrm{a}$ \\
\hline 105 & $0.49 \mathrm{a}$ & $2.22 \mathrm{ab}$ & $0.15 b$ & $60.99 \mathrm{a}$ \\
\hline \multicolumn{5}{|l|}{$\mathrm{CaCl}_{2}(\%)$} \\
\hline 0 & $0.43 \mathrm{~b}$ & $2.51 \mathrm{a}$ & $0.25 \mathrm{a}$ & $57.48 \mathrm{a}$ \\
\hline 1 & $0.47 \mathrm{ab}$ & $1.98 \mathrm{~b}$ & $0.29 \mathrm{a}$ & $62.70 \mathrm{a}$ \\
\hline 1.5 & $0.62 \mathrm{a}$ & $2.43 \mathrm{a}$ & $0.33 \mathrm{a}$ & $58.81 \mathrm{a}$ \\
\hline 2 & $0.52 \mathrm{ab}$ & $1.84 \mathrm{~b}$ & $0.35 \mathrm{a}$ & $61.67 \mathrm{a}$ \\
\hline $\begin{array}{c}\text { Interaction } \\
\left(\text { Variety } \times \mathrm{CaCl}_{2}\right)\end{array}$ & ns & * & ns & ns \\
\hline LSD & 0.17 & 0.42 & 0.16 & 12.32 \\
\hline
\end{tabular}

Means within a factor and column followed by the same alphabet were not significantly different at $p=0.05$ by using the LSD test. ${ }^{*}=$ significant and ns = not significant.

The ascorbic acid in the variety of 303 was $6.89 \%$ to $25.86 \%$ higher than the other varieties. The doses of $\mathrm{Ca}^{2+}(1.5 \%)$ showed that $30.64 \%$ higher and $\mathrm{Ca}^{2+}(2 \%)$ showed $17.30 \%$ higher vitamin $\mathrm{C}$ compared to the control and lower doses $(1 \%)$ of $\mathrm{CaCl}_{2}$, respectively. These findings go beyond the fact that ascorbic acid levels were highest in calcium-treated fruits and lowest in the control samples [9]. The peroxidase activity decreased in $\mathrm{CaCl}_{2}-$ treated tomato fruits as the ascorbate decreased the peroxidation of the cell wall polymers, leading to a more extensible cell wall and the retarded fruits' metabolic activity [34].

The essential pigment of lycopene is responsible for the characteristics of the deep red color of a tomato and the most abundant carotenoids present in ripened fruits. The interactive effects among the varieties and $\mathrm{CaCl}_{2}$ concentrations had significant differences $(p<0.05)$ in the amount of lycopene where the variety MT-3 showed $18.22 \%$ to $20.27 \%$ higher lycopene compared to the other varieties and the control treatment produced the 
highest amount of $26.15 \%$ to $34.78 \%$ lycopene compared to the $\mathrm{CaCl}_{2}$ treated samples, respectively (Table 4; Figure 2).

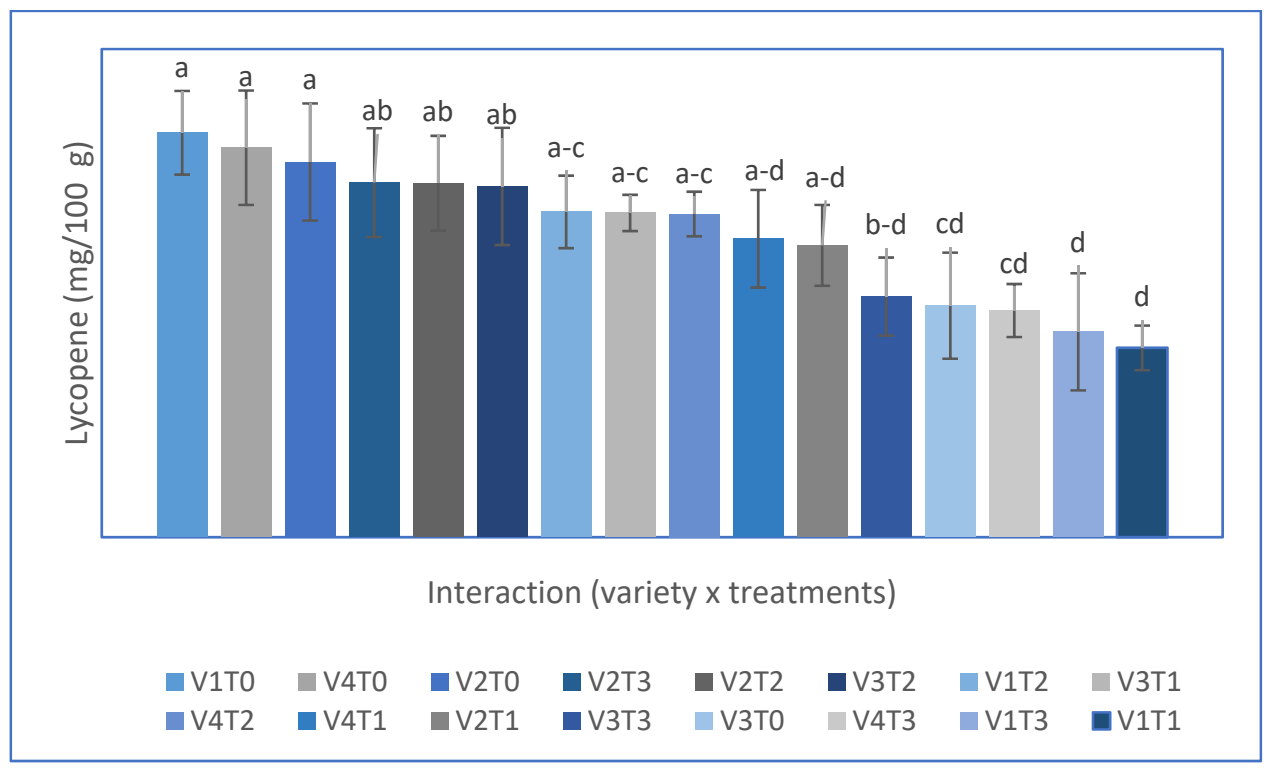

Figure 2. Effect of different lowland tomato varieties of V1; MT-1, V2; MT-3, V3; 303(H), and V4; 105(F1) and different doses of T0; $0, \mathrm{~T} 1 ; 1, \mathrm{~T} 2 ; 1.5$, and T3; 2 (\%) $\mathrm{CaCl}_{2}$ on the lycopene content of tomato fruits. Vertical bars indicate the standard error of means for four replicates. Means followed by the same alphabet were not significantly different at $p=0.05$ by using the LSD test.

Lycopene content in tomato fruits treated with $3 \% \mathrm{CaCl}_{2}$ in the 'Hasir Arun' cultivar of tomato fruits were lowest compared to the control treatment [38]. Similarly, immersing tomato fruits in $6 \% \mathrm{CaCl}_{2}$ for $20 \mathrm{~min}$ before harvest maintained post-harvest quality by retarding lycopene content, weight loss, and microbial deterioration [39]. The current findings support those of Tolasa et al. [40], who found that tomato fruits treated with $\mathrm{CaCl}_{2}$ had considerably lower lycopene concentration at room temperature.

\section{Total Phenolic Content (TPC) and DPPH}

The phenolic compounds are important plant constituents with redox properties responsible for antioxidant activity and the hydroxyl groups in plant extracts are responsible for facilitating free radicle scavenging. Interaction of varieties and $\mathrm{CaCl}_{2}$ concentrations on the total phenolic content were not significant $(p>0.05)$; however, considerable variances were found within the varieties (Table 4 ). The fruits of the MT-3 variety yielded the most TPC, which were $2.57 \%, 23.07 \%$, and $61.54 \%$ higher than the varieties of 105 , MT- 1 , and 303 , respectively.

The highest doses $\mathrm{CaCl}_{2}(2 \%)$ increased the amount of TPC at $5.72 \%$ to $28.57 \%$ higher than the lower doses and control samples, respectively. A similar trend was explained by Ranjbar et al. [41] that the retention of total phenolic content (TPC) in tomato fruits during storage was positively influenced by $\mathrm{CaCl}_{2}$. Moreover, Ca prevents senescenceinduced stress by maintaining the strength of the cell wall membrane [42]. The $\mathrm{CaCl}_{2}$ increased the strength of the fruit cell wall as well as the permeability of the membrane, which also reduces the rate of aging and declines phenol and the activity of polyphenol oxidase [43]. The increasing trends of TPC by the application of $\mathrm{CaCl}_{2}$ were also reported in persimmon by Bagheri et al. [44]. Although the interaction of the varieties and $\mathrm{CaCl}_{2}$ on the antioxidant activity (i.e., DPPH) did not have significant $(p>0.05)$ effects, variety 303 exhibited the maximum activity of $7.58 \%$ to $16.28 \%$ higher than the other varieties (Table 4). The DPPH radical scavenging activity was an $8.33 \%$ increase compared to the control with the application of low doses of $(1 \%) \mathrm{CaCl}_{2}$, which can be compared with the results concluded by Bagheri et al. [44], which showed that the accordance with the 
TPC and maximum antioxidant capacity was observed in $\mathrm{CaCl}_{2}$ treated fruits than the untreated samples.

\subsection{Postharvest Observation}

\subsubsection{Weight Loss}

The weight loss of fresh fruits and vegetables was mainly due to the loss of water (as a result of evaporation and transpiration), while the amount of dry matter was lost primarily to respiration. Table 5 shows that there were no three-way interaction effects $(p=0.05)$ between the tomato varieties, concentrations of $\mathrm{CaCl}_{2}$, and storage time (days) on the weight loss of tomato fruits. However, there were significant $(p<0.05)$ two-way interactions between tomato varieties $\times$ concentrations of $\mathrm{CaCl}_{2}$, tomato varieties $\times$ storage time, and concentrations of $\mathrm{CaCl}_{2} \times$ storage time on the weight loss of tomato fruits.

Table 5. Main and interaction effects of tomato varieties (MT-1, MT-3, 303, and 105), concentrations of $\mathrm{CaCl}_{2}(0,1,1.5,2 \mathrm{w} / \mathrm{\%})$, and storage time $(0,5,10,15,20$ days $)$ on percent weight loss, disease incidence, disease severity, and visual symptoms of tomato fruits stored at ambient temperature $\left(28 \pm 2{ }^{\circ} \mathrm{C}, 75 \pm 5 \% \mathrm{RH}\right)$.

\begin{tabular}{|c|c|c|c|c|}
\hline Treatment & $\begin{array}{l}\text { Weight Loss } \\
(\%)\end{array}$ & $\begin{array}{c}\text { Disease Incidence } \\
(\%)\end{array}$ & $\begin{array}{c}\text { Disease Severity } \\
(\%)\end{array}$ & $\begin{array}{c}\text { Visual Symptoms } \\
(\%)\end{array}$ \\
\hline \multicolumn{5}{|l|}{ Variety (V) } \\
\hline MT-1 & $8.70 \mathrm{a}$ & $5.70 \mathrm{a}$ & $1.00 \mathrm{a}$ & $2.69 c$ \\
\hline MT-3 & $6.65 b$ & $3.44 \mathrm{a}$ & $0.63 \mathrm{a}$ & $2.17 \mathrm{c}$ \\
\hline 303 & $6.71 \mathrm{~b}$ & $2.50 \mathrm{a}$ & $0.23 \mathrm{a}$ & $5.29 \mathrm{a}$ \\
\hline 105 & $5.03 \mathrm{c}$ & $2.50 \mathrm{a}$ & $0.41 \mathrm{a}$ & $3.85 \mathrm{~b}$ \\
\hline \multicolumn{5}{|l|}{$\mathrm{CaCl}_{2}(w / v, \%)$} \\
\hline 0 & $7.80 \mathrm{a}$ & $5.94 \mathrm{a}$ & $0.73 \mathrm{a}$ & $4.35 \mathrm{a}$ \\
\hline 1 & $6.62 b$ & $4.45 \mathrm{ab}$ & $0.90 \mathrm{a}$ & $3.66 \mathrm{~b}$ \\
\hline 1.5 & $6.54 \mathrm{~b}$ & $3.13 \mathrm{ab}$ & $0.47 \mathrm{a}$ & $3.31 \mathrm{~b}$ \\
\hline 2 & $6.14 b$ & $0.63 \mathrm{~b}$ & $0.18 \mathrm{a}$ & $2.69 c$ \\
\hline \multicolumn{5}{|l|}{ Storage time (ST) (day) } \\
\hline 5 & $2.48 \mathrm{~d}$ & $0.31 \mathrm{c}$ & $0.02 \mathrm{~b}$ & $0.59 \mathrm{~d}$ \\
\hline 10 & $5.41 \mathrm{c}$ & $1.02 \mathrm{bc}$ & $0.12 \mathrm{~b}$ & $1.95 \mathrm{c}$ \\
\hline 15 & $8.23 \mathrm{~b}$ & $5.31 \mathrm{ab}$ & $0.47 \mathrm{~b}$ & $3.96 \mathrm{~b}$ \\
\hline 20 & $10.97 \mathrm{a}$ & $7.50 \mathrm{a}$ & $1.66 \mathrm{a}$ & $7.50 \mathrm{a}$ \\
\hline $\begin{array}{l}\text { Interaction } \\
\mathrm{V} \times \mathrm{CaCl}_{2}\end{array}$ & $* *$ & ns & ns & ** \\
\hline $\mathrm{V} \times \mathrm{ST}$ & $* *$ & ns & ns & $* *$ \\
\hline $\mathrm{CaCl}_{2} \times \mathrm{ST}$ & * & ns & ns & ns \\
\hline $\mathrm{V} \times \mathrm{CaCl}_{2} \times \mathrm{ST}$ & ns & ns & ns & ns \\
\hline
\end{tabular}

Means within a factor and column followed by the same alphabet were not significantly different at $p=0.05$ by using the LSD test. * = significant, ${ }^{* *}=$ highly significant, $\mathrm{ns}=$ not significant.

Further examination of the significant interactions $(p<0.05)$ indicated that weight losses of tomatoes MT- 1 and 303 were highest with no $\mathrm{CaCl}_{2}$ application, followed by $1 \%$ $\mathrm{CaCl}_{2}$ application; meanwhile, weight losses were highest at $1.5 \% \mathrm{CaCl}_{2}$ application for tomatoes MT-3 and 105 (Figure 3).

The weight losses for tomato MT- 1 with no $\mathrm{CaCl}_{2}$ application were $30 \%, 39 \%$, and $113 \%$ higher than tomatoes MT-3, 303, and 105, respectively. The tomato fruits of MT-1 showed the highest weight loss at $1 \%$ and $2 \% \mathrm{CaCl}_{2}$ application, while tomato 105 showed the lowest weight loss at all treatments. There were also significant $(p<0.05)$ differences between tomato varieties and storage time in the weight loss of tomato fruits (Figure 4). 


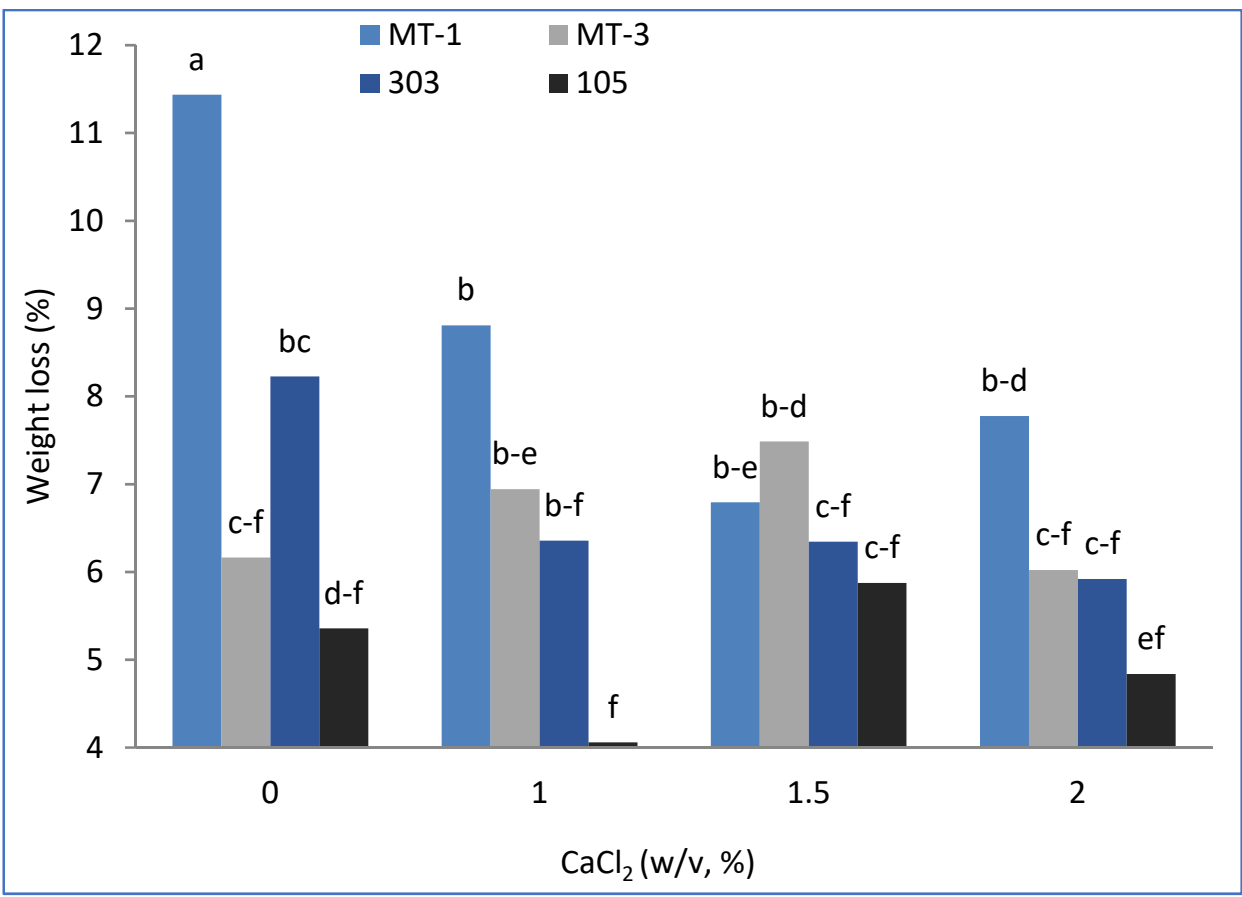

Figure 3. Weight loss of different tomato varieties (MT-1, MT-3, 303, and 105) at different concentrations of $\mathrm{CaCl}_{2}(0,1,1.5$, and $2 w / v \%)$ stored at ambient conditions for 20 days. LSD $=2.46$. Means following the same alphabet were not significantly different.

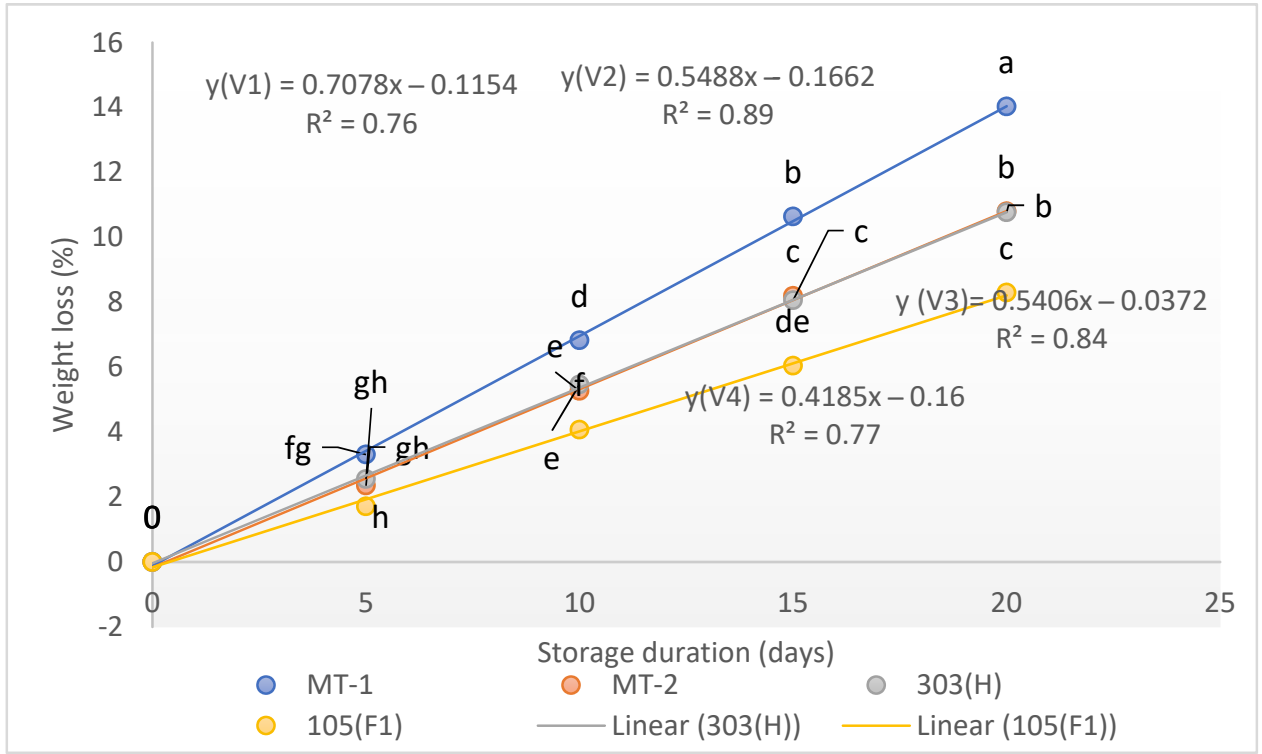

Figure 4. Weight loss of different tomato varieties (MT-1, MT-3, 303(H), and 105(F1) at different storage times $(5,10,15$, and 20 days $) \operatorname{LSD}=1.11$. Means following the same alphabet were not significantly different.

The weight loss of all tomato varieties increased linearly throughout the 20 days of storage time and on day 20, the weight losses of tomatoes were up to $14 \%$. MT-1 showed the highest weight loss among the four tomato varieties throughout the storage period, where about $30 \%, 30 \%$, and $69 \%$ weight loss was more elevated than the tomatoes MT-3, 303 , and 105, respectively, after 20 days of storage (Figure 4).

The results from the present study also showed a significant $(p<0.05)$ interaction effect between $\mathrm{CaCl}_{2}$ application and storage time on the weight loss of tomato fruits (Figure 5). The weight loss of tomato fruits at different doses of $\mathrm{CaCl}_{2}$ application during 
the postharvest experiment increased linearly as storage time extended. The weight loss of tomato fruits increased significantly $(p<0.05)$ and tomatoes with no $\mathrm{CaCl}_{2}$ application showed the highest weight loss compared to tomatoes with $\mathrm{CaCl}_{2}$ application. The weight loss of tomatoes with no $\mathrm{CaCl}_{2}$ application was $20 \%, 21 \%$, and $30 \%$ higher than tomatoes with $1 \%, 1.5 \%$, and $2 \% \mathrm{CaCl}_{2}$ application, respectively, after 20 days of storage. The higher $\mathrm{Ca}$ concentration in treated tomato fruits contributes to the network formation of $\mathrm{Ca}$ with pectin, named as calcium-pectate complexes, which restrict the cell wall from losing moisture from the tomato fruit matrix [7].

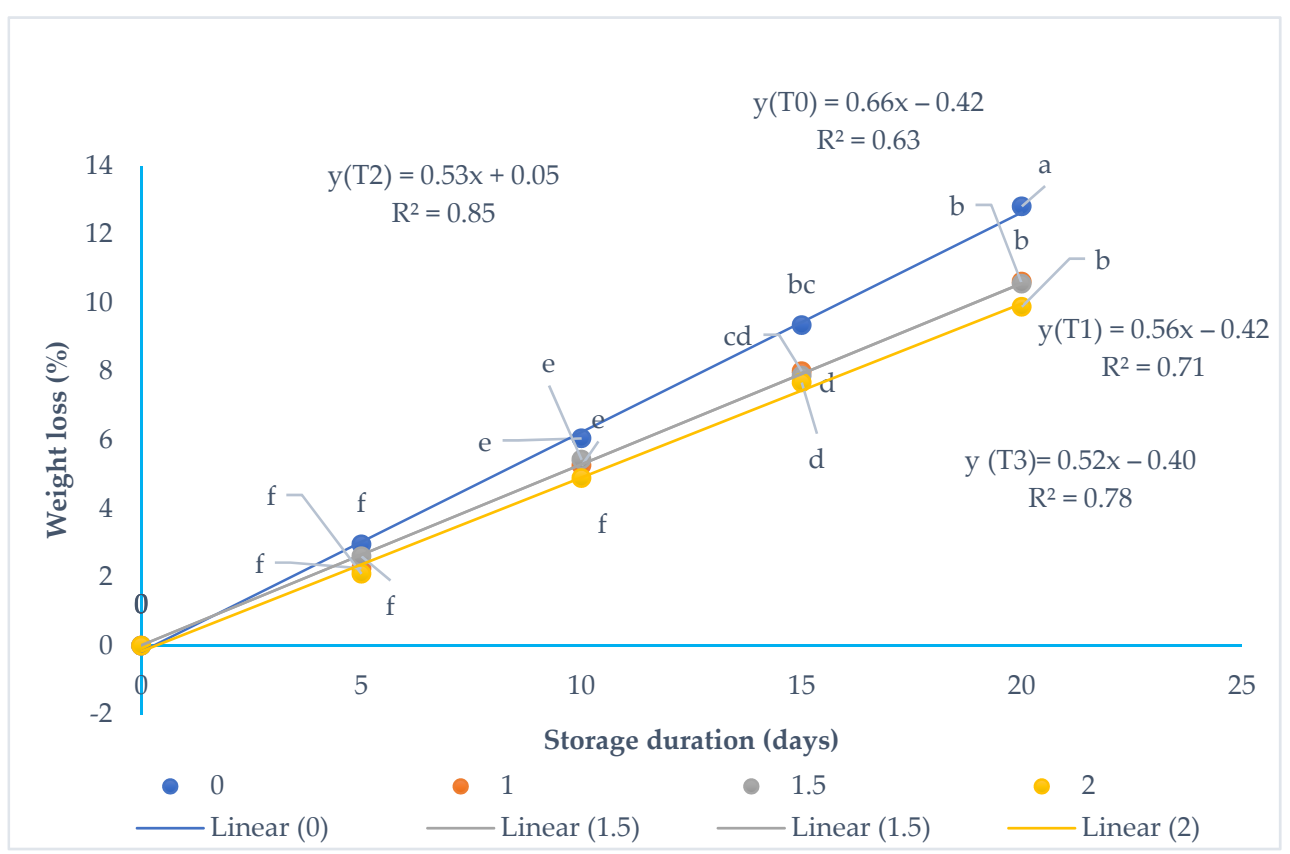

Figure 5. Weight loss of tomato fruits at different concentrations of $\mathrm{CaCl}_{2}(0,1,1.5$, and $2 \% w / v)$ at different storage times $(5,10,15$, and 20 days $) \operatorname{LSD}=1.43$. Means following the same alphabet were not significantly different.

The $\mathrm{CaCl}_{2}$ maintained the integrity and functionality of the cell membrane of tomato fruits, resulting from high firmness and low moisture loss [33]. Overall, following the findings reported by Patrick and Arthur [45], the application of $\mathrm{CaCl}_{2}$ can minimize weight loss, excessive shrinkage, spoilage, and decreased the different metabolic stresses after harvest in tomato fruits.

\subsubsection{Disease Incidence and Disease Severity}

The disease severity is the percentage of relevant host tissues or organs covered by the symptom or lesion by pathogen and measured by the number and sizes of the lesion present on the fruit surface. Table 5 shows there were no interaction $(p>0.05)$ effects on tomato varieties, concentrations of $\mathrm{CaCl}_{2}$, and different storage duration on disease incidence (DI) and disease severity (DS) at ambient storage conditions $\left(28 \pm 2{ }^{\circ} \mathrm{C}, 75 \pm 5 \%\right.$ $\mathrm{RH})$. Besides that, there were no significant $(p>0.05)$ differences among the tomato varieties in disease incidence (DI) and disease severity (DS), but a significant $(p<0.05)$ difference was found in the disease incidence (DI) for tomatoes with no $\mathrm{CaCl}_{2}$ application and $2 \%$ $\mathrm{CaCl}_{2}$ application. The DI in tomato with no $\mathrm{CaCl}_{2}$ application was eight times higher than the DI in tomato with $2 \% \mathrm{CaCl}_{2}$ application. Meanwhile, with and without $\mathrm{CaCl}_{2}$ application on tomato fruits showed no significant $(p>0.05)$ difference in DS. Generally, DI and DS in tomato fruits caused by different types of fungus and molds, which increased gradually as the storage time (days) increased.

The present study revealed that there was a significant $(p<0.05)$ difference in the DI of tomatoes in a storage period of five days and 20 days (Table 5). DI of tomato in 
20 days of storage was ten times higher than the DI of tomato in five days of storage; whereas the DS in tomato at 20 days' storage was the highest among the other storage time. Overall, these findings follow the conclusions reported by Daundasekera et al. [33] where the pre-harvest application of $\mathrm{CaCl}_{2}$ on immature fruits could extend the longevity of tomatoes by increasing the firmness, delay skin color development, and retard the fungal rot development in tomato fruits. Moreover, the $\mathrm{Ca}^{2+}$ ion reduced the fruit softening by strengthening the cell wall, acting as an antifungal activity that declined the respiration rate, ripening process, and pathogenic infection during storage [46]. The deficiency of calcium in fruits would increase the cell membrane permeability, thus permitting ions to escape for the breakdown of intercellular compartmentalization responsible for accelerating the fruit ripening and softening process [47].

\subsubsection{Visual Symptoms}

Calcium has been extensively used to improve the fruit quality, and delaying shrinkage in storage ultimately extended the shelf life of various fruits [48]. There were no three-way significant interaction effects $(p>0.05)$ among the tomato varieties, different concentrations of $\mathrm{CaCl}_{2}$, and different storage duration on \% visual symptoms of tomato fruits (Table 5).

The result revealed that the visual symptoms (\%) of all tomato varieties with and without $\mathrm{CaCl}_{2}$ application were increased as storage duration extended and decreased with the extending rate of $\mathrm{CaCl}_{2}$ (Figure 6). Among all the varieties, the tomato fruits of MT-3 showed the lowest visual symptoms compared to others whereas the variety 303 appeared with the maximum symptoms. On the other hand, after 20 days of storage duration, MT-3 fruits showed the lowest symptoms with the highest doses of $\mathrm{CaCl}_{2}$ compared to other doses and varieties where the variety 303 appeared to have the maximum visual symptoms (Table 5).

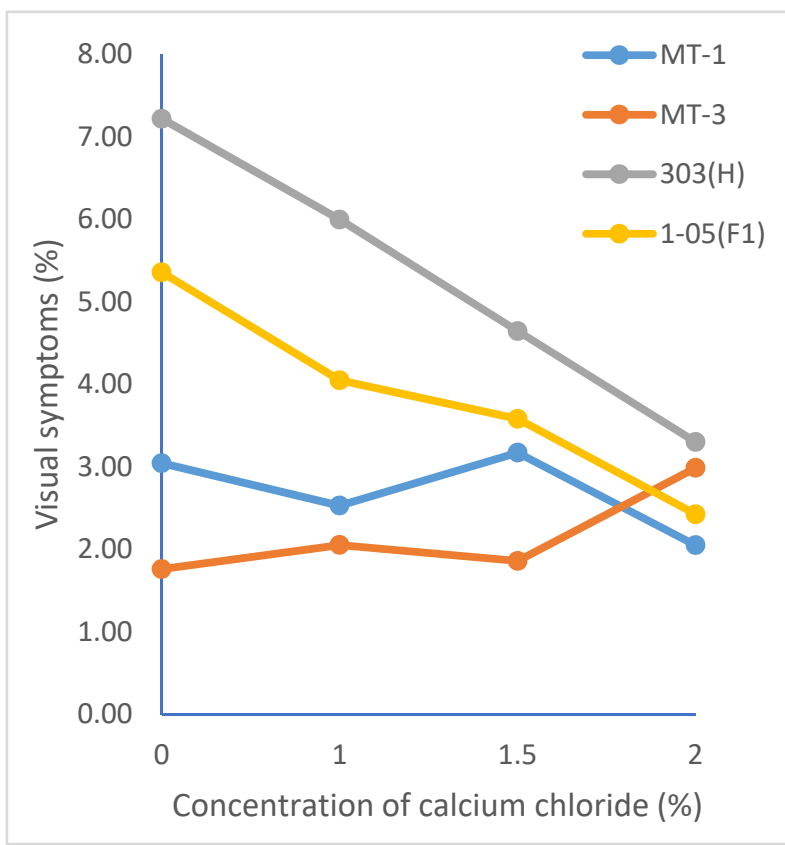

(A)

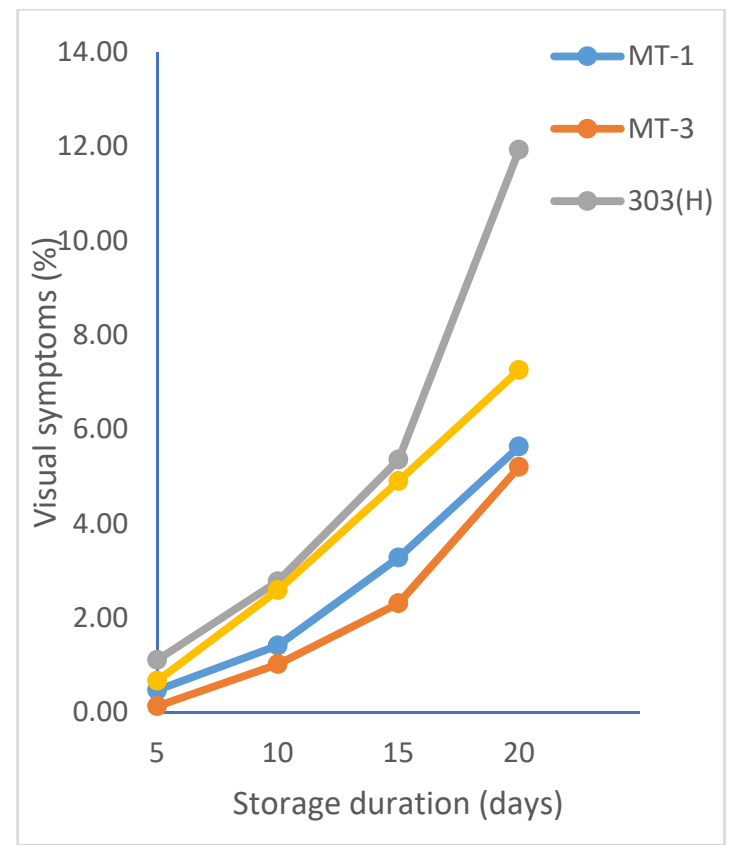

(B)

Figure 6. Percent visual symptoms of varieties of MT-1, MT-3, 303(H), and 105(F1) with the interaction of $\mathrm{CaCl}_{2}(0,1,1.5$, and $2 \%)(A)$ and storage durations $\left(5,10,15\right.$, and 20 days). (B) Stored at ambient temperature $\left(28 \pm 2{ }^{\circ} \mathrm{C}, 75 \pm 5 \mathrm{RH}\right)$. Vertical bars indicate the standard error of means for four replicates. Prior to analysis, the arcsin data transformation was performed on the percent data. 


\subsubsection{Shelf Life}

$\mathrm{CaCl}_{2}$ has been extensively used to improve the fruit quality, and delaying shrinkage in storage conditions ultimately extended the shelf life of various fruits [47]. In our experiment, tomato varieties MT-3 and 105 maintained the marketable quality of fruits up to 20 days of storage compared to the varieties of MT-1 and 303 (Figure 7A).
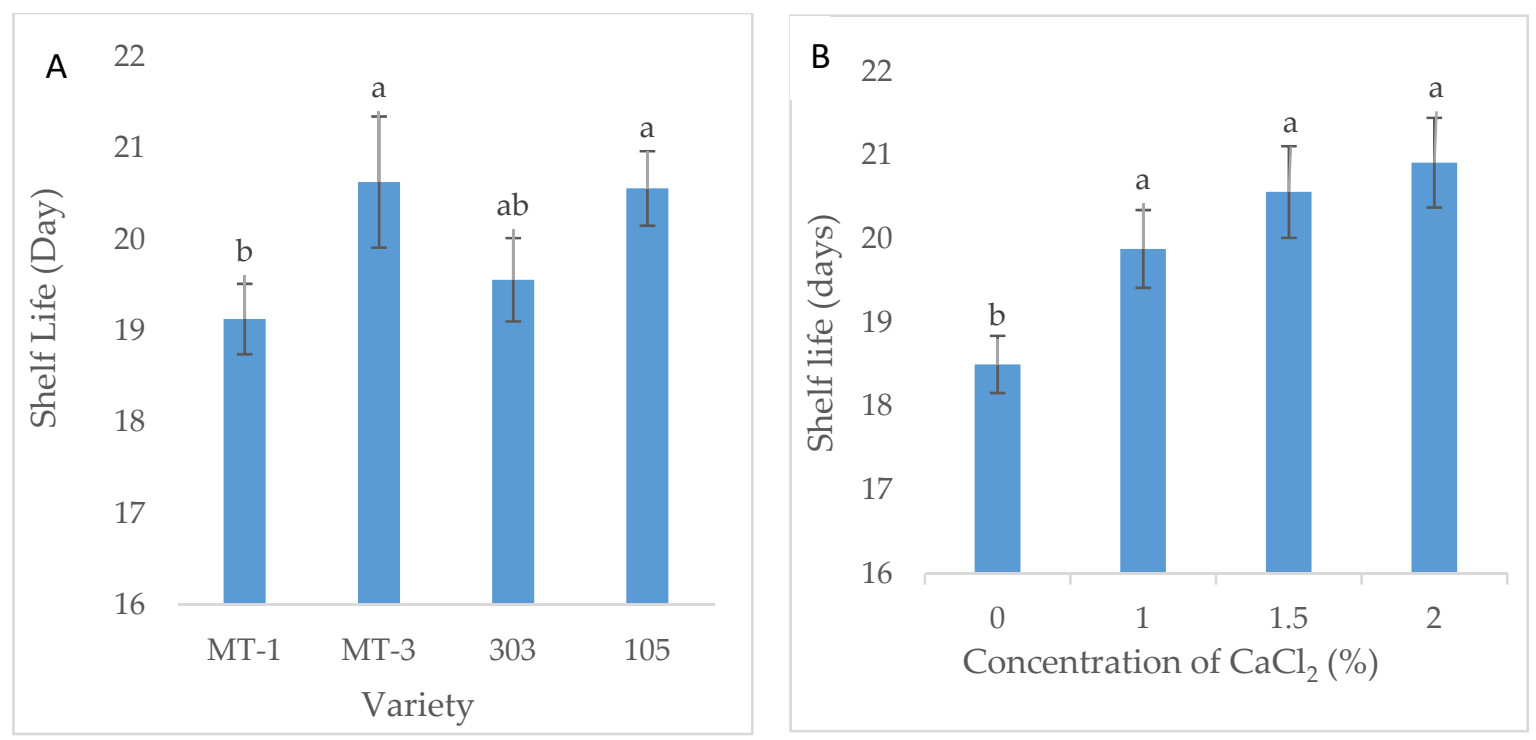

Figure 7. Effect of different low land tomato varieties (A) of MT-1, MT-3, 303(H), and 105 (F1) and different doses of 0, 1, 1.5, and $2(\%) \mathrm{CaCl}_{2}$ (B) on the shelf life of tomato fruits stored at ambient temperature $\left(28 \pm 2{ }^{\circ} \mathrm{C}\right.$ and $\left.75 \pm 5 \% \mathrm{RH}\right)$. Vertical bars indicate the standard error of means for four replicates. Means following the same alphabet were not significantly different.

The different doses of $\mathrm{CaCl}_{2}$ responded differently. The higher doses (2\%) played a vital role in maintaining fruit quality than the untreated and lower doses up to 20 days of ambient temperature (Figure 7B). The extension of storage duration was attributed mainly to the increase in the firmness and retarded the rate of ethylene production by applying $\mathrm{CaCl}_{2}$ (Table 3) [10]. It was also demonstrated by Daundasekera et al. [33] that preharvest application of $\mathrm{CaCl}_{2}$ on tomatoes could be used in extending the postharvest longevity of fruits mainly through increasing firmness, delayed skin color development, and to some extent retarded fungal rot development. The application of $\mathrm{CaCl}_{2}$ to improve the shelf life of different fruits was presented by Kirmani et al. [48] in palms, and Chauhan et al. [49] in mango.

\section{Conclusions}

The higher doses of $\mathrm{CaCl}_{2}(2 \%)$ play an important role in controlling the blossom end rot of two hybrid tomatoes, 303 and 105 varieties, but had no significant $(p<0.05)$ effects on the growth and yield parameters. The tomato variety MT-3 showed better results regarding growth, yield, disease, and insect infestation among the four lowland tomato varieties. For the postharvest part, the pre-harvest application of $\mathrm{CaCl}_{2}$ played a significant $(p<0.05)$ role in increasing the fruit firmness, especially in the MT-3 variety. The pre-harvest foliar application of $\mathrm{CaCl}_{2}$ showed highly positive effects on firmness at maximum doses $(2 \%)$ of $\mathrm{CaCl}_{2}$. An increasing dose of $\mathrm{CaCl}_{2}$ decreased the postharvest disease incidence $(\%)$ and disease severity $(\%)$ of all varieties, but increased with the increase in the duration of storage. No significant $(p>0.05)$ differences were observed in the rate of ethylene production in both cases, but the respiration rate decreased with the increasing concentration of $\mathrm{CaCl}_{2}(\%)$. Overall, this study revealed that the pre-harvest application of $2 \% \mathrm{CaCl}_{2}$ on immature fruits could solve physiological disorders such as blossom end rot, thus extending the postharvest longevity mainly through increasing the firmness of tomato fruits. 
Author Contributions: Conceptualization, A.M. (Azizah Misran) and M.N.N.M.; Data curation, M.N.N.M.; Formal analysis, A.M. (Azizah Misran) and M.N.N.M.; Funding acquisition, A.M. (Azizah Misran) and M.N.N.M.; Investigation, A.M. (Azizah Misran), P.D., P.E.M.W. and A.M. (Azhar Mohamad); Methodology, A.M. (Azizah Misran) and M.N.N.M.; Supervision, A.M. (Azizah Misran) and P.E.M.W.; Validation, A.M. (Azizah Misran), P.D., P.E.M.W. and A.M. (Azhar Mohamad); Visualization, A.M. (Azizah Misran), P.D., P.E.M.W. and A.M. (Azhar Mohamad); Writing—original draft, M.N.N.M. and A.M. (Azizah Misran); Writing-review \& editing, M.N.N.M. and A.M. (Azizah Misran). All authors have read and agreed to the published version of the manuscript.

Funding: This research work was supported by the Bangladesh Agricultural Research Council (BARC) through the research grant of the National Agricultural Technology Program-Phase II (NATP-2), Bangladesh.

Institutional Review Board Statement: Not applicable.

Informed Consent Statement: Not applicable.

Data Availability Statement: The raw data supporting the conclusions of this article will be made available by the authors without undue reservation.

Acknowledgments: We would like to thank the Bangladesh Institute of Nuclear Agriculture (BINA) and Universiti Putra Malaysia (UPM) for the continuous support to perform the research activities in Malaysia.

Conflicts of Interest: The authors declare no conflict of interest.

\section{Appendix A}

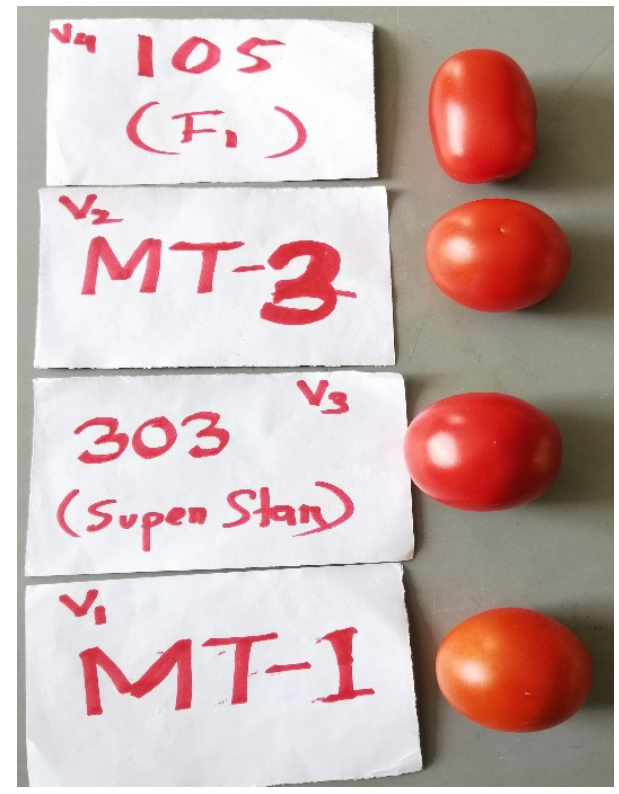

Figure A1. Four lowland tomato varieties. 


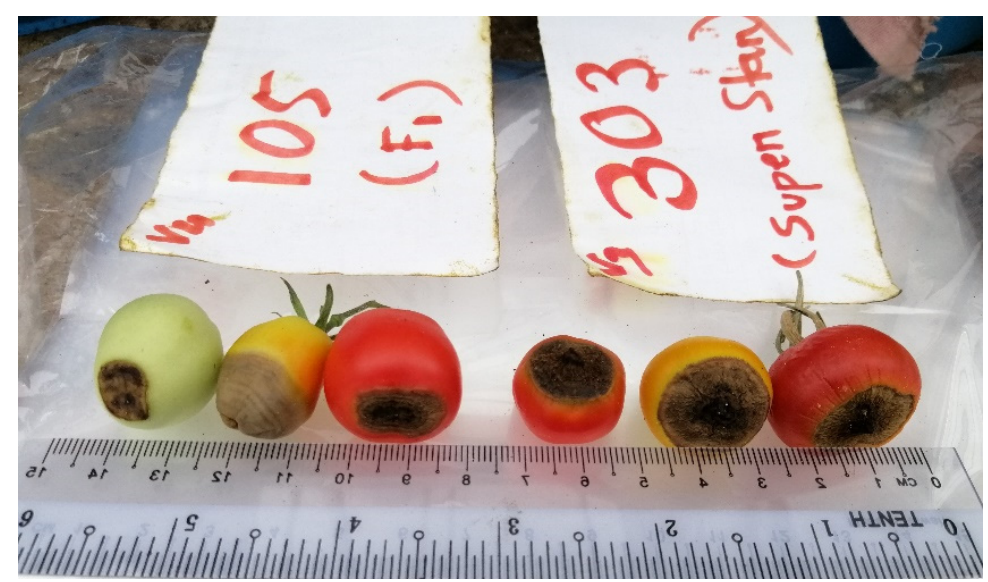

Figure A2. Blossom end rot symptoms in lowland tomato varieties (303 and 105).

\section{References}

1. Safari, Z.S.; Ding, P.; Zahidi, N.M.; Atif, A.; Wafa, S.; Aziz, A.; Yusoff, S.F. Maintenance of defence enzyme activities in tomato fruit during storage by chitosan and vanillin coating. Int. J. Appl. Sci. Res. 2021, 4, 177-188.

2. Arah, I.K.; Kumah, E.K.; Anku, E.K.; Amaglo, H. An overview of postharvest losses in tomato production in Africa: Causes and possible prevention strategies. J. Biol. Agric. Healthc. 2015, 5, 78-88. Available online: https://www.iiste.org/Journals/index. $\mathrm{php} / \mathrm{JBAH} /$ article/view/25134 (accessed on 24 December 2020).

3. FAOSTAT. Production-Crops-Area Harvested/ Production Quantity-Tomatoes-2019. Available online: http://www.fao. org/faostat/en/\#data/QC/visualize (accessed on 20 April 2021).

4. Cheng, H.M.; Koutsidis, G.; Lodge, J.K.; Ashor, A.; Siervo, M.; Lara, J. Tomato and lycopene supplementation and cardiovascular risk factors: A systematic review and meta-analysis. Atherosclerosis 2017, 257, 100-108. [CrossRef] [PubMed]

5. Rehman, M.; Khan, N.; Jan, I. Postharvest losses in tomato crop (a case study of Peshawar Valley). Sarhad J. Agric. 2007, 23, 1279-1284. Available online: https://www.aup.edu.pk/sj_pdf/POST\%20HARVEST\%20LOSSES\%20IN\%20TOMATO\%20CROP. pdf (accessed on 15 January 2021).

6. Beckles, D.M. Factors affecting the postharvest soluble solids and sugar content of tomato (Solanum lycopersicum L.) fruit. Postharvest Biol. Technol. 2012, 63, 129-140. [CrossRef]

7. Genanew, T. Effect of postharvest treatments on storage behavior and quality of tomato fruits. World J. Agric. Sci. 2013, 9, 29-37. [CrossRef]

8. Anjum, S.; Hamid, A.; Ghafoor, A.; Tahira, R.; Shah, S.Z.A.; Awan, S.I.; Ahmad, K.S. Evaluation of biochemical potential in tomato (Solanum lycopersicum) germplasms. Pak. J. Agric. Sci. 2020, 57, 177-187.

9. Abbasi, N.A.; Zafar, L.; Khan, H.A.; Qureshi, A.A. Effects of naphthalene acetic acid and calcium chloride application on nutrient uptake, growth, yield, and postharvest performance of tomato fruit. Pak. J. Bot. 2013, 45, 1581-1587. Available online: https:/ / www.researchgate.net/publication/256458112 (accessed on 10 February 2021).

10. Senevirathna, P.A.W.A.N.K.; Daundasekera, W.A.M. Effect of postharvest calcium chloride vacuum infiltration on the shelf life and quality of tomato (cv.'Thilina'). Ceylon J. Sci. 2010, 39, 35-44. [CrossRef]

11. Bhattarai, D.R.; Gautam, D.M. Effect of harvesting method and calcium on postharvest physiology of tomato. Nepal Agric. Res. J. 2006, 7, 37-41. [CrossRef]

12. Michailidis, M.; Karagiannis, E.; Tanou, G.; Samiotaki, M.; Tsiolas, G.; Sarrou, E.; Molassiotis, A. Novel insights into the calcium action in cherry fruit development revealed by high-throughput mapping. Plant Mol. Biol. 2020, 104, 597-614. [CrossRef]

13. Michailidis, M.; Polychroniadou, C.; Kosmidou, M.A.; Petraki-Katsoulaki, D.; Karagiannis, E.; Molassiotis, A.; Tanou, G. An Early Calcium Loading during Cherry Tree Dormancy Improves Fruit Quality Features at Harvest. Horticulturae 2021, 7, 135. [CrossRef]

14. Michailidis, M.; Karagiannis, E.; Tanou, G.; Karamanoli, K.; Lazaridou, A.; Matsi, T.; Molassiotis, A. Metabolomic and physicochemical approach unravel dynamic regulation of calcium in sweet cherry fruit physiology. Plant Physiol. Biochem. 2017, 116, 68-79. [CrossRef] [PubMed]

15. Tejashvini, A. Growth and yield attribute as influenced by calcium foliar nutrition under poly-house condition. Int. J. Pure Appl. Biosci. 2018, 6, 952-957. [CrossRef]

16. Hanna, H.Y. Influence of cultivar, growing media, and cluster pruning on greenhouse tomato yield and fruit quality. Hort. Technol. 2009, 19, 395-399. Available online: http:/ / horttech.ashspublications.org/ (accessed on 7 November 2020). [CrossRef]

17. Rahim, H.; Wahab, M.A.M.A.; Amin, M.Z.M.; Harun, A.; Haimid, M.T. Technological adoption evaluation of agricultural and food sectors towards modern agriculture: Tomato. Econ. Technol. Manag. Rev. 2017, 12, 41-53. Available online: http: / / etmr.mardi.gov.my /Content/ETMR\%20Vol.12/Vol12_5.pdf (accessed on 21 January 2021). 
18. Perez-Harguindeguy, N.; Diaz, S.; Garnier, E.; Lavorel, S.; Poorter, H.; Jaureguiberry, P.; Bret-Harte, M.S.; Cornwell, W.K.; Craine, J.M.; Gurvich, D.E.; et al. Corrigendum to: A new handbook for standardized measurement of plant functional traits worldwide. Aust. J. Bot. 2016, 64, 715-716. [CrossRef]

19. Gbollie, S.N.; Mwonga, S.M.; Kibe, A.M. Effects of Calcium Nitrate Levels and Soaking Durations on Cocopeat Nutrient Content. J. Agric. Chem. Environ. 2021, 10, 372-388.

20. Cox, D. Water quality: PH and alkalinity. University of Massachusetts Extension. Dep. Plant Soil Sci. Massa 1995, 50-51.

21. Kumah, P.; Olympio, N.S.; Tayviah, C.S. Sensitivity of three tomatoes (Lycopersicon esculentum) cultivars-Akoma, Pectomech, and power-to-chilling injury. Agric. Biol. J. 2011, 2, 799-805. Available online: http://hdl.handle.net/123456789/7180 (accessed on 17 September 2020).

22. Nirupama, P.; Neeta, B.G.; Ramana Rao, T.V. Effect of Postharvest Treatments on Physicochemical Characteristics and Storage life of Tomato (Lycopersicon esculentum Mill.) Fruits during Storage. Am. Eurasian J. Agric. Environ. Sci. 2010, 9, 470-479. Available online: http:/ / idosi.org/aejaes/jaes9/3.pdf (accessed on 10 November 2020).

23. Mohammadi-Aylar, S.; Jamaati-e-Somarin, S.; Azimi, J. Effect of stage of ripening on mechanical damage in tomato fruits. Am. Eurasian J. Agric. Environ. Sci. 2010, 9, 297-302. Available online: http://www.idosi.org/aejaes/jaes9/12.pdf (accessed on 10 November 2020).

24. Ding, P.; Mashah, N.C. Growth, maturation, and ripening of underutilized Carissa congesta fruit. Fruits 2016, 71, 171-176. [CrossRef]

25. Nagata, M.; Yamashita, I. A simple method for simultaneous determination of chlorophyll and carotenoids in tomato fruit. Nippon Shokuhin Kogyo Gakkaishi 1992, 39, 925-928. Available online: http:/ / cse.naro.affrc.go.jp/mnagata/pigment2.pdf (accessed on 4 July 2020). [CrossRef]

26. Addai, Z.R.; Abdullah, A.; Mutalib, S.A. Influence of ripening stages on antioxidant properties of papaya fruit (Carica papaya L.). AIP Conf. Proc. 2013, 1571, 696-701. [CrossRef]

27. Musa, K.H.; Abdullah, A.; Jusoh, K.; Subramaniam, V. Antioxidant activity of pink-flesh guava (Psidium guajava L.): Effect of extraction techniques and solvents. Food Anal. Methods 2011, 4, 100-107. [CrossRef]

28. Zhu, S.H.; Zhou, J. Effect of nitric oxide on ethylene production in strawberry fruit during storage. Food Chem. 2007, 100, 1517-1522. [CrossRef]

29. Amadi, J.; Nnamani, C.; Ozokonkwo, O.; Eze, C.S. Survey of the incidence and severity of okra (Abelmoschus esculentus L. Moench) Fruit rot in Awka South lga, Anambra state, Nigeria. Int. J. Curr. Microbiol. Appl. Sci. 2014, 3, 1114-1121. Available online: http:/ / eprints.gouni.edu.ng/id/eprint/1363 (accessed on 11 February 2021).

30. SAS Institute. SAS 9.4 Output Delivery System: User's Guide; SAS Institute: Cary, NC, USA, 2014.

31. Ayyub, C.M.; Pervez, M.A.; Shaheen, M.R.; Ashraf, M.I.; Haider, M.W.; Hussain, S.; Mahmood, N. Assessment of various growth and yield attributes of tomato in response to pre-harvest applications of calcium chloride. Pak. J. Life Soc. Sci. 2012, 10, 102-105. Available online: http:/ / www.pjlss.edu.pk/pdf_files/2012_2/4.\%20Research\%20Paper\%20102--105.pdf (accessed on 9 August 2020).

32. Daundasekera, W.A.M.; Liyanage, G.L.S.G.; Wijerathne, R.Y.; Pieris, R. Preharvest calcium chloride application improves postharvest keeping quality of tomato (Lycopersicon esculentum Mill.). Ceylon J. Sci. 2015, 44, 55-60. [CrossRef]

33. Rab, A.; Haq, I.U. Foliar application of calcium chloride and borax influences plant growth, yield, and quality of tomato (Lycopersicon esculentum Mill.) fruit. Turk. J. Agric. For. 2012, 36, 695-701. Available online: https://journals.tubitak.gov.tr/ agriculture/issues/tar-12--36--6/tar-36--6-8--1112--7.pdf (accessed on 21 December 2020).

34. Braga, M.A.; Marques, T.R.; Simao, A.A.; Botelho, L.N.S.; Oliveira, L.S.D.; Abreu, C.M.P.D. Mechanism of firmness loss in guava cv. Pedro Sato during ripening at room temperature. Food Sci. Technol. 2017, 38, 26-32. [CrossRef]

35. Madani, B.; Mirshekari, A.; Yahia, E. Effect of calcium chloride treatments on calcium content, anthracnose severity, and antioxidant activity in papaya fruit during ambient storage. J. Sci. Food Agric. 2016, 96, 2963-2968. [CrossRef] [PubMed]

36. Peyvast, G.; Olfati, J.A.; Ramezani-Kharazi, P.; Kamari-Shahmaleki, S. Uptake of calcium nitrate and potassium phosphate from foliar fertilization by tomato. J. Hortic. For. 2009, 1, 7-13. [CrossRef]

37. Mujtaba, A.; Masud, T.; Butt, S.J.; Qazalbash, M.A.; Fareed, W.; Shahid, A. Potential role of calcium chloride, potassium permanganate, and boric acid on quality maintenance of tomato cv. Rio grandi at ambient temperature. Int. J. Biol. Sci. 2014, 5, 9-20. [CrossRef]

38. Mishra, S.; Prakash, V. Biochemical changes in calcium chloride treated Hisar Arun (Local) and Kashi Vishesh (Hybrid) cultivars of Tomato fruit. Curr. Agric. Res. J. 2018, 6, 395. [CrossRef]

39. Eric, A.; Oduro, I.; Kumah, P. Postharvest quality response of tomato (Lycopersicon esculentum, Mill) fruits to different concentrations of calcium chloride at different dip-times. Am. J. Food Nutr. 2015, 5, 1-8.

40. Tolasa, M.; Gedamu, F.; Woldetsadik, K. Impacts of harvesting stages and pre-storage treatments on shelf life and quality of tomato (Solanum lycopersicum L.). Cogent Food Agric. 2021, 7, 1863620. [CrossRef]

41. Ranjbar, S.; Rahemi, M.; Ramezanian, A. Comparison of nano-calcium and calcium chloride spray on postharvest quality and cell wall enzymes activity in apple cv. Red Delicious. Sci. Hortic. 2018, 240, 57-64. [CrossRef]

42. Hassnain, H.; Basit, A.; Alam, M.; Ahmad, I.; Ullah, I.; Alam, N.; Ullah, I.; Khalid, M.A.; Shair, M.; Zafar, N. Efficacy of Chitosan on Performance of Tomato (Lycopersicon esculentum L.) Plant under Water Stress Condition. Pak. J. Agric. Res. 2020, 33, 27. [CrossRef] 
43. Torres, L.M.A.R.; Silva, M.A.; Guaglianoni, D.G.; Neves, V.A. Effects of heat treatment and calcium on postharvest storage of atemoya fruits. Aliment. E Nutr. Araraquara 2010, 20, 359-367.

44. Bagheri, M.; Esna-Ashari, M.; Ershadi, A. Effect of postharvest calcium chloride treatment on the storage life and quality of persimmon fruits (Diospyros kaki Thunb.) cv.'Karaj'. Int. J. Hortic. Sci. Technol. 2015, 2, 15-26. Available online: https: / /ijhst.ut.ac.ir/article_54260_7334.html (accessed on 20 October 2020).

45. Patrick Kumah, I.O.; Arthur, E. Effect of maturity stage and postharvest calcium chloride treatment on the quality and storage life of tomatoes (Lycopersicon esculentum Mill). J. Postharvest Technol. 2015, 3, 74-81.

46. Gayed, A.A.N.A.; Shaarawi, S.A.M.A.; Elkhishen, M.A.; Elsherbini, N.R.M. Pre-harvest application of calcium chloride and chitosan on fruit quality and storability of 'Early Swelling'peach during cold storage. Food Sci. Technol. Ciênc. Agrotec 2017, 41, 220-231. [CrossRef]

47. Deytieux-Belleau, C.; Vallet, A.; Donèche, B.; Geny, L. Pectin methylesterase and polygalacturonase in the developing grape skin. Plant Physiol. Biochem. 2008, 46, 638-646. [CrossRef]

48. Kirmani, S.N.; Wani, G.M.; Wani, M.S.; Ghani, M.Y.; Abid, M.; Muzamil, S.; Raja, H.; Malik, A.R. Effect of preharvest application of calcium chloride $\left(\mathrm{CaCl}_{2}\right)$, Gibberlic acid $\left(\mathrm{GA}_{3}\right)$, and Napthelenic acetic acid (NAA) on storage of Plum (Prunus salicina L.) cv. Santa Rosa under ambient storage conditions. Afr. J. Agric. Res. 2013, 8, 812-818. [CrossRef]

49. Chauhan, S.; Gupta, K.C.; Agrawal, M. Efficacy of chitosan and calcium chloride on postharvest storage period of mango with the application of hurdle technology. Int. J. Curr. Microbiol. Appl. Sci. 2014, 3, 731-740. Available online: https: / / www.ijcmas.com/vol-3--5/Shweta\%20Chauhan,\%20et\%20al.pdf (accessed on 13 February 2021). 